\title{
Loss given default in SME leasing
}

\section{Florian Kaposty ${ }^{1} \cdot$ Philipp Klein $^{1}$ (D) - Matthias Löderbusch ${ }^{1} \cdot$ Andreas Pfingsten $^{1}$}

Received: 28 March 2020 / Accepted: 21 July 2021 / Published online: 2 September 2021

(c) The Author(s) 2021

\begin{abstract}
Leasing provides a fundamental source of firm funding, especially for small and medium-sized enterprises. A crucial difference from loans and bonds is that the lessor retains ownership rights of the leased asset during the lease term. This facilitates the asset utilization and work-out process and leads to higher liquidation proceeds. Hence, previous findings on the loan and bond loss given default (LGD) are not transferable to the leasing industry. Our analysis is based on a very granular data set covering a great variety of information on the lessee, the leased asset, as well as contractual and transactional characteristics. We examine novel LGD determinants such as an external credit rating, the lessee's limited liability, and the number of leased assets and collaterals. Moreover, new results on previously explored factors question earlier findings, for example, on the lease contract type. Most importantly, as proposed by Miller and Töws (J Bank Finance 91:189-201, 2018), we analyze two different LGDs, one based on the asset utilization proceeds, the other on repayments. Our results clearly indicate the crucial importance of this separation when analyzing the drivers of the leasing LGD in detail because several determinants affect these LGDs in different ways. Our study assists both lessors and regulators in assessing the effective risk of lease contracts and enables lessors to enhance their risk management and work-out processes.
\end{abstract}

Keywords Credit risk $\cdot$ leasing $\cdot \mathrm{SME}$ financing $\cdot$ Loss given default

JEL Classification G21 · G23 · G28 · G32 · G33

Philipp Klein

philipp.klein@wiwi.uni-muenster.de

Florian Kaposty

florian.kaposty@t-online.de

Matthias Löderbusch

loederbusch.m@gmail.com

Andreas Pfingsten

andreas.pfingsten@wiwi.uni-muenster.de

1 Finance Center Munster, University of Münster, Universitätsstr. 14-16, 48143 Munster, Germany 


\section{Introduction}

Leasing has grown rapidly in the recent past and currently constitutes an essential source of firm funding, providing an alternative to more traditional financing instruments, such as equity or bank loans (e.g., Leaseurope 2015; European Central Bank 2018). Particularly for small and medium-sized enterprises (SMEs), leasing presents an attractive financing vehicle (e.g., Eisfeldt and Rampini 2009; European Central Bank 2019). However, the assessment of risk figures for SME financing turns out to be a particularly onerous task for banks and potential investors alike due to the paucity of information on SME business characteristics (e.g., Sharpe and Nguyen 1995; Dietsch and Petey 2002; Berger and Udell 2006; Tang et al. 2017). Notably, financing with equity or bank loans is much more sensitive to asymmetric information between the bank and the SME as opposed to underwriting lease contracts, since the latter is primarily dependent on leased asset valuation (Lasfer and Levis 1998; Eisfeldt and Rampini 2009).

For loans, the loss given default (LGD) is a key credit risk driver (see Grunert and Weber 2009 and the references therein). For leasing, the LGD assumes even greater importance, as there are major particularities of lease contracts (HartmannWendels et al. 2014). Most importantly, the legal title of the leased asset remains with the lessor during the term, and the lessee only obtains the right to use the asset. Consequently, Eisfeldt and Rampini (2009) point out that the repossession of leased assets is considerably easier than exploiting the collateral of defaulted loans. This is even more pronounced because asset disposals are not limited to defaulted contracts; therefore, asset disposals are a core business of leasing institutions. Furthermore, the lessor is permitted to retain the overall utilization proceeds. As a result, the recovery rates of lease contracts regularly exceed $100 \%$, which explains why the LGD becomes negative (e.g., Schmit and Stuyck 2002; Laurent and Schmit 2005). Consequently, the LGDs of lease contracts are lower than loan or bond LGDs on average (e.g., De Laurentis and Riani 2005; Helwig 2008).

The specific credit risk characteristics of lease contracts are also mirrored by regulatory requirements and accounting standards. As a case in point, for leasing, the credit risk capital requirements for the internal ratings-based approach allow lessors to treat uncollateralized leases as collateralized ones (Art. 211 Capital Requirement Regulation (CRR)) if (among other requirements) the lessor remains the legal owner of the leased asset. ${ }^{1}$ This condition is fulfilled in most lease contracts. Additionally, until 2018 most leases were only reported on the lessor's balance sheet, except for hire-purchase contracts. Only as a consequence of the new IFRS 16 accounting standard, which became effective in 2019, the vast majority of leases have to be included on the lessee's balance sheet as well, implying several disclosure and risk management requirements (International Accounting Standards Board 2016). Furthermore, lessors are also forced to more comprehensively disclose risks arising

\footnotetext{
1 The US bankruptcy legislation also takes this into account and further simplifies asset repossession in the case of lease contracts (US Bankruptcy Code Chapter 11 and Eisfeldt and Rampini (2009)).
} 
from the legal ownership and sale of the leased asset. This especially includes a detailed expected loss estimation, emphasizing the important role of the LGD.

As lease contracts and loans and bonds do not share all the same characteristics, their LGD determinants cannot be identical. However, some features are similar, and it is not surprising that the literature on leasing has found a few LGD determinants that are already known as determinants of loan LGDs (e.g., Schmit and Stuyck 2002; De Laurentis and Riani 2005; Miller 2016). Building on the fact that recoveries of lease contracts originate from two distinct sources, liquidation proceeds and payments from the lessee and collateralization, several empirical analyses also provide a number of leasing-specific LGD determinants, but the results sometimes differ considerably in detail (for a detailed presentation of leasing LGD determinants, see Sect. 3; e.g., Schmit and Stuyck 2002; Schmit 2004; De Laurentis and Riani 2005; Pirotte and Vaessen 2008; Elbracht 2011; Miller 2016). ${ }^{2}$

In our study, we utilize a very granular data set of 26,750 lease contracts with SMEs, containing 1156 contracts which defaulted between 2009 and 2014. This data set provides a great variety of potential exogenous drivers of the LGD, including all characteristics required by the European regulator (European Banking Authority 2017), and allows us to use explanatory variables from five groups: (1) Backstops, (2) Contract and Lessee Characteristics, (3) Default Characteristics, (4) Object Characteristics, and (5) Lessee's Industry. In our analysis, we not only utilize a valuable data set but also apply a variety of methods: Tobit, Probit, and Spline regression models, the variable selection procedure proposed by Frank and Goyal (2009), a backward selection as well as the two-stage Heckman selection model.

In the results, we replicate some findings of the earlier literature. We find, for example, a negative impact of the variable proportion of the exposure at default (EAD) to the original lease contract balance, a negative impact of the object type vehicles, and a positive impact of the work-out duration on the LGD (e.g., Schmit and Stuyck 2002; Schmit 2004; Pirotte and Vaessen 2008; Elbracht 2011; for details, see Sect. 4). These results indicate that our data set behaves well on charted territory and is therefore well suited for use to extend the exploration to uncharted territory. Based on this data set, we add to the ongoing debate on the impact of the macroeconomic environment on the LGD in leasing, which exhibits ambiguous findings in prior studies, by revealing a significantly negative impact of the GDP growth rate on the LGD (e.g., Hartmann-Wendels and Honal 2010; Miller 2016). We also derive some results which contradict earlier findings, notably on the effect of hire-purchase contracts, the effect of lending relationship, and LGDs for electronic devices (e.g., De Laurentis and Riani 2005; Elbracht 2011; Miller 2016). In general, the abovementioned disagreement across previous empirical studies concerning particular LGD determinants may result from the use of different, sometimes rather small, sets

\footnotetext{
${ }^{2}$ Related literature examines the accuracy of different LGD estimation techniques, while the influence factors of the LGD are mainly untouched (see for leasing LGDs, e.g., Hartmann-Wendels et al. 2014; Miller and Töws 2018, and for loan LGDs, e.g., Bastos 2010; Yashkir and Yashkir 2013; Hurlin et al. 2018). Beyond these analyses, Kaposty et al. (2020) additionally analyze the importance of single determinants for the accuracy of LGD predictions using different forecasting techniques. The results reveal that leased asset value and characteristics as well as the interest rate exhibit the highest predictive power.
} 
of variables. Thus, an even more important contribution is to enrich the list of potential LGD determinants with four variables from three of the five categories, which to the best of our knowledge were not included in any earlier studies on leasing LGDs: number of collaterals, number of leased assets, lessee's limited liability, and lessee's external credit rating. Especially the latter two variables typically matter for credit risk, and it is surprising that they are missing from the leasing LGD literature.

Our most important contribution is the separate analysis of LGDs, calculated based on either the liquidation proceeds or the payments from the lessee and collateralization. In the previous literature, Schmit and Stuyck (2002) and Laurent and Schmit (2005) provide initial evidence on these separate LGDs. Hartmann-Wendels and Honal (2010) and Miller (2016) show that the two components behave significantly differently, for example, over the business cycle, and Miller and Töws (2018) prove that a separate estimation is advantageous for the quality of the LGD estimation. But a parallel full-scale analysis of their determinants was still missing, and we fill this gap. Our results reveal that contract, lessee, and default characteristics are the most important determinants of the LGD based on the liquidation proceeds, whereas the LGD based on the payments only hinges on the backstops and the workout duration. These backstops comprise lessees' liability and the collateralization of the contract. The fact that a longer work-out duration increases the overall LGD and the LGD based on liquidation proceeds but decreases the LGD arising from payments further highlights the value of a separate analysis of these two LGDs.

The remainder of this paper is structured as follows: Sect. 2 introduces our data set and the LGD as our endogenous variable. In Sect. 3, we present the (presumed) determinants, related literature, and summary statistics. In Sect. 4, we demonstrate and discuss our results. Robustness checks are provided in Sects. 5 and 6 concludes.

\section{Data and LGD as the endogenous variable}

\subsection{Data}

Our analysis is premised on a very granular data set provided by a mid-sized German bank. Banks, together with manufacturer-affiliated firms and independent leasing companies, constitute the supply side of the German as well as the European leasing market (see here and in the following, Leaseurope (2017) and Association of German Leasing Companies (2019)). Lessors' sizes range from small entities up to leasing divisions of globally leading banks and manufacturers of cars or machines. Even though the wide range of different companies is a key trait of the leasing industry, the main properties of our data provider reflect important characteristics of the banks in the German and European leasing markets.

Our initial data set consists of a total of 26,750 active and terminated lease contracts with SMEs from 2001 up to 2014. SMEs constitute a major customer group of lease contracts in Europe. The portfolio contains detailed information on the leased asset, lessee, contractual, and transactional characteristics as well as contractual and realized payments both during the life of the lease and after its default. In total, 1189 contracts defaulted between April 2009 and December 2014. We drop five 
contracts from the initial sample because their EAD is negative and two with negative repayments, as these values are implausible. For the purpose of the exogenous variable calculation, we have to drop 26 observations on account of missing data. Thus, our final sample contains 1,156 defaulted contracts. Importantly, the recovery process for collecting outstanding debt is completed for all contracts.

In the online appendix, Figure A.1 and Table A.1 show that the distribution of the contract age at default is right-skewed and first defaults occur after very few months of contract duration, as well as that the majority of the defaulted contracts default up to the fifth contract year. Consistently, the average contract age at default is found to be about 2.5 years, which is in line with the data set of Miller and Töws (2018).

Our access to the entire leasing portfolio of the bank enables us to show that our final data set is representative of both the entire portfolio and the whole German and European leasing markets. By matching the type of leased objects and lessee's industry in our final data set with the entire leasing portfolio as well as information published by Kraemer-Eis and Lang (2012), Oxford Economics (2015), the Association of German Leasing Companies (2016), and Leaseurope (2016), we are able to confirm that our sample largely reflects the initial contract distribution as well as the general structure of both the German and European leasing markets. While different market surveys seem to yield slightly disparate results when observing either the number of SME lessees or the market volumes of leasing financings, our data set, if at all, only marginally underrepresents Factory and Office Equipment and Electronic Devices compared to our entire data set and the overall leasing market, respectively (see Table A.2 in the online appendix for a detailed comparison).

\subsection{Loss given default as the endogenous variable}

We analyze the $L G D$ as our main endogenous variable. Our definition of default is based on the bank's definition, which itself mainly relies on the definition from the regulatory requirements. Therefore, a contract is defaulted on if the lessee has become insolvent or the lessor has canceled the contract because the lessee is overdue with payments. In accordance with Art. 178 (CRR) and previous research on the leasing LGD (e.g., Hartmann-Wendels and Honal 2010), the latter definition of default is not assigned to a lessee but to a contract in our study. Importantly, lease contracts, in contrast to loans, are inherently connected with leased assets which are necessary to run the company's business (e.g., Leaseurope 2013). As a lessee's default on a contract usually results in the lessor's timely claim of repossession of the leased asset, which we actually observe in our data set, the lessee may prioritize the repayments of different contracts in case of financial distress and still meet the payments for those contracts whose leased assets are particularly necessary for the business activity. However, we observe only 13 lessees exhibiting both active as well as canceled contracts.

$L G D$ is defined as one minus the recovery rate (RR), that is, one minus the ratio of revenues collected by the bank after the default of a contract to the exposure 
outstanding at the time of default. ${ }^{3}$ Revenues consist of the sum of utilization proceeds from the leased asset exploitation and the payments collected by the bank from the lessee and the collateralization (Table 1). Consequently, $L G D$ is defined as follows:

$$
L G D:=1-\frac{\text { Liquidation proceeds }+ \text { Payments }}{\text { Exposure at Default }}
$$

In conformity with the literature (e.g., Laurent and Schmit 2005; Miller and Töws 2018), we use the two major components of $L G D$ and define $L G D^{\text {Asset }}$ and $L G D^{\text {Payment }}$ separately:

$$
L G D^{\text {Asset }}:=1-\frac{\text { Liquidation proceeds }}{\text { Exposure at Default }}, \quad L G D^{\text {Payment }}:=1-\frac{\text { Payments }}{\text { Exposure at Default }} .
$$

In line with other studies on leasing LGDs (e.g., Schmit and Stuyck 2002; Laurent and Schmit 2005; Hartmann-Wendels and Honal 2010; Hartmann-Wendels et al. 2014), we observe that, unlike loans' LGDs, $L G D$ in our sample is not restricted to the interval between 0 and 1 (see Fig. 1 and Table 1) as the lessor remains the leased asset's legal owner and is permitted to retain the overall utilization proceeds. The lowest value of $L G D$ equals $-376 \%$, whereas the mean amounts to $37 \%{ }^{4}$ We obtain 108 defaulted contracts exhibiting a negative value of $L G D$, that is, the recovery rate is larger than one. In line with previous studies, Fig. 1 also illustrates that $L G D$ peaks at values around 0 and $100 \%$ as well as between 40 and $50 \%$. Overall, the distribution of our $L G D$ observations resembles closely the findings in the literature, reaffirming the representativeness of our data set (e.g., Elbracht 2011; HartmannWendels et al. 2014).

Based on lease contractual terms, the leased asset is the first and most important source of recovery. Consequently, $L G D^{\text {Asset }}$ is far lower than $L G D^{\text {Payment }}$ which indicates that the utilization of the leased asset primarily constitutes $L G D$. In our sample, the bank was able to realize any utilization proceeds in $94 \%$ of the contracts, whereas the bank receives payments from lessee or the collateral only in $35 \%$ of the contracts.

\footnotetext{
${ }^{3}$ We refrain from incorporating costs in the derivation of $L G D$ for several reasons. First, the extant empirical literature on loans and leasing provides initial evidence that incorporating costs affects $L G D$ only marginally (e.g., Franks et al. 2004; De Laurentis and Riani 2005). This is especially pronounced because the defaults in the portfolio occurred during a period of historically low and decreasing interest rates in Europe. Second, the bank considers and enters costs as general expenses, which makes an attribution to single contracts hardly feasible. Third, we are not provided with detailed information on the time distribution of the cash flows collected by the bank between a contract's default and the end of the work-out process.

${ }^{4}$ In robustness tests, we address possible concerns due to very low values of $L G D$ in our data set, which may be classified as outliers (see Sect. 5 and Table A.12 in the online appendix).
} 
Table 1 Descriptive statistics for our main endogenous variables

\begin{tabular}{llllllllll}
\hline Variable & Mean & SD & Min & p10 & p50 & p90 & Max & Skew. & Kurt. \\
\hline$L G D$ & 0.37 & 0.38 & -3.76 & 0.00 & 0.39 & 0.79 & 1.00 & -2.35 & 21.82 \\
$L G D^{\text {Asset }}$ & 0.44 & 0.34 & -3.76 & 0.05 & 0.45 & 0.83 & 1.00 & -2.31 & 25.96 \\
$L G D^{\text {Payment }}$ & 0.93 & 0.21 & -2.20 & 0.78 & 1.00 & 1.00 & 1.00 & -5.43 & 52.41 \\
\hline
\end{tabular}

NB: This table reports the descriptive statistics of our endogenous variables $L G D, L G D^{A s s e t}$, and $L G D^{\text {Payment }}$. All numbers are based on our 1156 defaulted contracts. "Mean" ("SD", "Min", "Max", "Skew.", "Kurt.") describes the mean (standard deviation, minimum, maximum, skewness, kurtosis) and "p10" ("p50", "p90") the 10th (50th, 90th) percentile of the endogenous variables distribution. Comprehensive variable definitions are provided in Sect. 2.2

\section{Determinants of LGD in leasing}

We incorporate a large set of explanatory variables and classify them into five groups: Backstops, Contract and Lessee Properties, Default Characteristics, Object Characteristics, and Lessee's Industry. ${ }^{5}$ The variables are described below and defined in Table 2. Summary statistics are provided in Table 3 and pairwise correlations in Table A. 3 in the online appendix. ${ }^{6}$

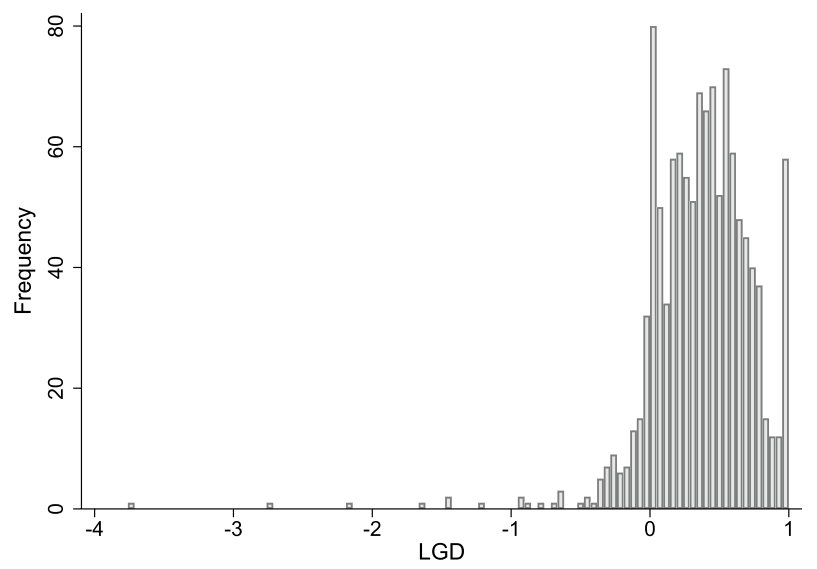

Fig. 1 Histogram of $L G D$ for the 1,156 defaulted lease contracts in our sample

\footnotetext{
5 We additionally provide a broad compilation of studies analyzing the leasing LGD and its determinants in Table 1. Moreover, we provide a bivariate analysis by splitting our $L G D$ observations with respect to the dummy variables in Table A.4 in the online appendix. We observe whether $L G D$ significantly differs when grouped on the basis of these variables.

${ }^{6}$ Given that the variance inflation factors yield on average 2.0 and all factors are smaller than 5.1, it can be inferred that multicollinearity does not undermine our analysis.
} 


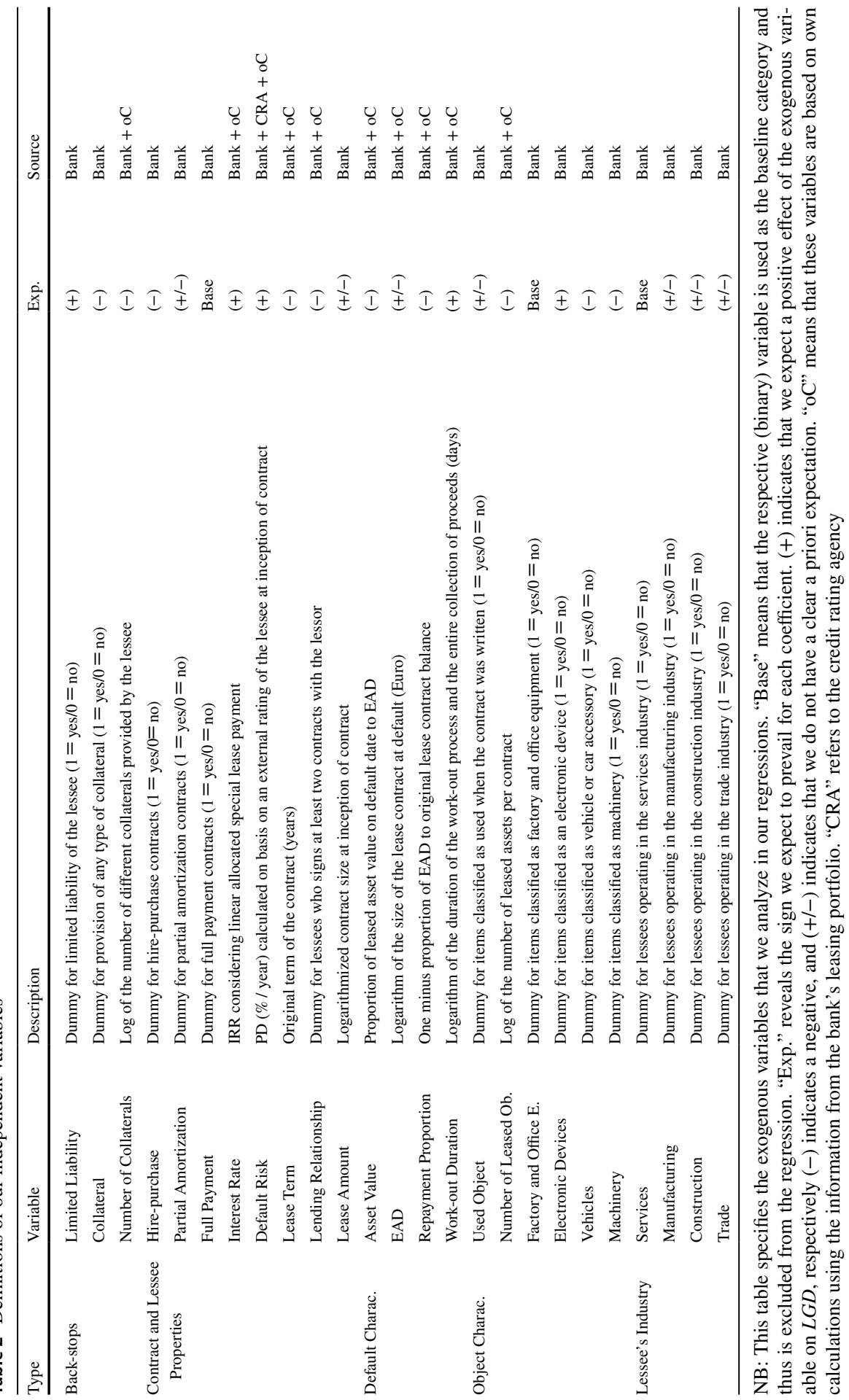




\subsection{Backstops}

Companies with limited liability are generally expected to exhibit higher LGDs as only the assets of a distressed firm instead of the firm's assets and, additionally, the personal wealth of the owner ensure the repayments. Additionally, lessees with limited liability are more likely to neglect the maintenance of the leased asset or, if existing, physical collateral since the potential losses are restricted to the firm's wealth (e.g., Pykhtin 2003). In a first analysis for lease contracts, De Laurentis and Riani (2005) suggest that recovery rates significantly vary with respect to the lessee's legal form of organization, such as sole proprietorship or corporation. To the best of our knowledge, a direct link between firms having limited liability and the LGD remains missing in the literature on both loans and leases. We complement the literature by including a dummy variable Limited Liability and predict a higher $L G D$ arising out of both a higher $L G D^{\text {Asset }}$ as well as a higher $L G D^{\text {Payment }}$.

As the lessor remains the legal owner of the leased asset, additional collateral is generally less common in leasing than for bank loans. For the same reason, third party guarantees and personal securities are the most prominent types of collateral (e.g., De Laurentis and Riani 2005). Even if a bank requires additional collateral for contracts involving moral hazard problems or higher anticipated LGDs, the empirical results unambiguously reveal a negative effect of collateralization on LGDs (e.g., De Laurentis and Riani 2005; Elbracht 2011). Therefore, we include Collateral and, beyond the literature, Number of Collaterals as a more precise measure for multiple collateralization since we observe several contracts which exhibit a number of collaterals. Providing collateral is assumed to negatively affect $L G D$ by a decreasing $L G D^{\text {Payment }}$ and intensified by a larger Number of Collaterals.

\subsection{Contract and Lessee Properties}

Lease contracts can essentially be classified into three different types: full payment leases, partial amortization leases, and hire-purchases. In full payment leases the contract terms oblige continuous repayments, increasing the ratio of leased asset value to outstanding lease volume. In contrast, partial amortization leases comprise a major balloon payment at contract maturity. Finally, in hire-purchase contracts the lessee aims or is even obliged to buy the hired asset at the end of the contract period, increasing the incentive to maintain the asset more conscientiously (Eisfeldt and Rampini 2009). Elbracht (2011) and Miller (2016) show a negative impact of hire-purchase lease contracts on the LGD. Therefore, we predict a negative impact of Hire-purchase on $L G D$ and $L G D^{\text {Asset }}$ as compared to our baseline category Full Payment, whereas Hire-purchase does not affect $L G D^{\text {Payment }}$. As different payment structures of Partial Amortization and Full Payment are captured by our further explanatory variables (e.g., Repayment Proportion), we do not assume different influences of these contract types.

Borrowers with poor creditworthiness are more likely to increase their firm risk when running into default, which, in turn, leads to higher losses if default occurs 
(for loans and bonds, e.g., Altman et al. 2005; Hu and Perraudin 2006; Pan and Singleton 2008). In leasing, Miller (2016) shows mixed results on the impact of the implicit interest rate as well as the overall interest rate level on the LGD. We incorporate both the contract's Interest Rate as a measure for the internal risk assessment, lessors' interest rate risk provision, and funding costs, as well as an external rating Default Risk. ${ }^{7}$ The latter refers to a specialized credit rating for German SMEs. Based on the rating, we calculate the probability of default (PD) expected by the rating agency. ${ }^{8}$ This variable enables us to take the isolated effect of the lessee's creditworthiness into account, clearly enhancing the measurement of the lessee's credit risk. The correlation coefficient of 0.08 between Interest Rate and Default Risk further underpins the major importance of the separate consideration of these LGD determinants. We expect a positive sign of Interest Rate and Default Risk on LGD.

Second, several studies examine the effect of the lease term to maturity. Schmit and Stuyck (2002) and De Laurentis and Riani (2005) reveal a negative relationship between LGD and maturity, whereas Miller (2016) mainly obtains insignificant coefficients. According to the literature, we take Lease Term into consideration and predict a negative sign of the coefficient.

Third, if the lessor and lessee exhibit a close relationship, information asymmetries are reduced and the lessee has an incentive to maintain its reputation in order to get further leases in the future (e.g., Kysucky and Norden 2016). For loans, the lending relationship is predominantly associated with lower LGDs (e.g., Dermine and Neto de Carvalho 2006; Grunert and Weber 2009; Ertan et al. 2017). With regard to lease contracts, Miller (2016) shows ambiguous results. Following the literature (e.g., Grunert and Weber 2009; Ertan et al. 2017), we include Lending Relationship as a dummy variable indicating whether the lessor and lessee have signed at least two contracts. This is the most suitable measure we can calculate within our data set, but we acknowledge that we do not have detailed information on the business relationship prior to our observation period or on the standard credit business of the bank. ${ }^{9}$ We hypothesize that a closer lessor-lessee contact goes along with lower $L G D, L G D^{\text {Asset }}$, and $L G D^{\text {Payment }}$.

\footnotetext{
${ }^{7}$ We acknowledge possible issues regarding the correlation of default risk, interest rate, and $L G D$ as well as the fact that realized values of $L G D$ can only be observed in the case of lessee's default, and thus, only observations of $L G D$ conditional on the default event are available (e.g., Heckman 1979; Bade et al. 2011; Rösch and Scheule 2014; Krüger et al. 2018). Therefore, we address these issues in our robustness tests (see Sect. 5 as well as Tables A.7, A.10, and A.9 in the online appendix). Our findings remain the same when taking these issues into account.

8 The classification of borrowers resembles credit ratings for individuals, for example the Schufa score in Germany or the FICO score in the US, and therefore differs fundamentally from ratings by the major international rating agencies, which typically do not rate SMEs. To provide further robustness to the definition of Default Risk, we re-estimate our main regression using the initial rating score (see Sect. 4.1 and Table A.5 in the online appendix).

${ }^{9}$ To provide further evidence on the impact of the business relation, we re-estimate our model without the Lending Relationship and additionally replace this variable with the distance between the lessor's and lessee's headquarters (Distance), in line with Grunert and Weber (2009) and Agarwal and Hauswald (2010). The results are presented in Tables A.16 and A.17 in the online appendix and show that our results on the further determinants do not rely on the definition of Lending Relationship, but Distance does not significantly affect $L G D$.
} 


\subsection{Default characteristics}

As derived above, the leased asset is pivotal when analyzing the LGD in leasing. Consequently, we take the proportion of the leased asset value at default to the EAD into account by calculating this value using the information on official tax depreciation periods in our data set. ${ }^{10}$ To the best of our knowledge, this factor has only been analyzed by Miller (2016). The analysis reveals both significantly negative and insignificant results of the relative leased asset value. We suggest a negative impact of Asset Value on $L G D$ and $L G D^{\text {Asset }} .^{11}$

Regarding $E A D$, De Laurentis and Riani (2005) provide empirical evidence of a positive correlation between $E A D$ and LGD in lease contracts, whereas Elbracht (2011) reveals a negative relation. In line, Jiménez and Saurina (2004) and Dermine and Neto de Carvalho (2006) show ambiguous results for loans. We do not expect a specific direction of $E A D$ in our analysis.

Pirotte and Vaessen (2008) stress that the amortization payment schedule is mostly linear and partially includes a balloon payment at maturity (see Sect. 3.2), while the value of the leased asset is convex over time. Pirotte and Vaessen (2008) and Miller (2016) show that the LGD of lease contracts decreases with a higher quotient of payments made up to the default date divided by the original lease volume. Consequently, we include Repayment Proportion and expect a negative effect on $L G D$ as well as $L G D^{\text {Asset }}$.

Longer work-out processes arising from, for example, difficulties in gaining repossession of the leased asset are associated with declining leased asset values and thus increase the LGD. On the contrary, a long work-out process may enable the lessor to benefit from worthwhile but extensive lessee liquidations, as lengthy recovery processes are usually conducted only when expecting sufficient liquidation proceeds. Previous studies confirm higher LGDs for bank loans or debt with longer work-out durations (e.g., Van de Castle et al. 2000; Grossman et al. 2001), and Elbracht (2011) supports this finding for lease contracts as well. We predict a positive sign of Duration Work-out with respect to $L G D$ and $L G D^{\text {Asset }}$ but a negative sign in case of $L G D^{\text {Payment }}$.

\subsection{Object characteristics}

Prior research on leasing broadly suggests that the LGD varies considerably across object types (e.g., Schmit 2004; De Laurentis and Riani 2005; Hartmann-Wendels and Honal 2010). We follow the most frequently used classification in literature and

\footnotetext{
10 According to the lessor's accounting standards of hire-purchase leases (see the description of contract types above), we lack the depreciation period information in this case. Therefore, we estimate these periods in an additional regression model based on the data of the other contract types. The impact of the remaining variables is remarkably unaffected by including the asset value at default.

11 Our definition Asset Value is based on an annual depreciation rate of $30 \%$. To be more conservative, we re-estimate our main regression using Asset Value based on a linear depreciation. These results are reported in Table A.18 in the online appendix and are found to be completely consistent with our main results.
} 
practice and include four dummy variables for the object types in our analysis (e.g., Hartmann-Wendels et al. 2014; Leaseurope 2018). Based on the results in the literature, we expect a negative impact of Vehicles or Car Accessories and Machinery on $L G D$ and $L G D^{\text {Asset }}$ as compared to our baseline category Factory and Office Equipment, observing the strongest negative effect of Vehicles or Car Accessories (e.g., Schmit and Stuyck 2002; Schmit 2004; De Laurentis and Riani 2005). In contrast, the literature shows that Electronic Devices exhibit the highest LGDs (e.g., Elbracht 2011; Miller 2016).

Evaluating the impact of the leased asset on the LGD in greater detail, we include Used Object and Number of Leased Objects. First, a Used Object may have a lower loss of value, which is typically highest in the first month of product life. Contrastingly, the resale opportunities of a Used Object hinge on the asset maintenance of at least two lessees. However, Elbracht (2011) and Miller (2016) do not find significant results of this impact factor and thus we do not expect a significant impact of Used Object. Second, bundling various objects in one contract decreases the risk of particularly low utilization proceeds as the lessor has various sales opportunities. Thus, the probability of obtaining revenues increases; therefore, the LGD reduces. Our granular data set allows us to define the log of the number of leased objects (Number of Leased Objects) per contract and to include this variable as the first study expecting a negative impact on $L G D$ and $L G D^{\text {Asset }}$.

\subsection{Lessee's industry}

Industries tend to differ in various aspects, such as competitiveness, international relations, speed of innovation, and many more. Although these factors may partially be included in other variables, the results in the literature show that some genuine effects of Lessee's Industry persist (e.g., De Laurentis and Riani 2005; Elbracht 2011). We also control for this factor by including the lessee's industry classification as categorical variables, which may particularly affect $L G D^{\text {Payment }}$.

\section{Empirical results}

\subsection{Main regression analysis}

We analyze $L G D\left(L G D^{\text {Asset }}, L G D^{\text {Payment }}\right)$ as our dependent variable with respect to our five different sets of explanatory variables, as discussed in Sect. 3:

$$
\begin{aligned}
\text { LGD }_{i}= & \beta_{0}+\beta_{1} \times \text { Backstops }_{i}+\beta_{2} \times \text { Contract and Lessee Properties }_{i} \\
& +\beta_{3} \times \text { Default Characteristics } \text { Pr }_{i}+\beta_{4} \times \text { Object Characteristics }_{i} \\
& +\beta_{5} \times \text { Lessees Industry }_{i}+\text { Default Year }_{t}+\epsilon_{i} .
\end{aligned}
$$

$i \in\{1, \ldots, 1,156\}$ indexes contracts, $t \in\{2009, \ldots, 2014\}$ refers to years, $\beta_{1}$ to $\beta_{5}$ represent the regression coefficients, and $\epsilon_{i}$ is the error term.

A well-known problem in the context of LGD regressions is that $L G D$ is bounded from above at 1 (if work-out costs are not incorporated). This might lead 
Table 3 Descriptive statistics for our explanatory variables

\begin{tabular}{|c|c|c|c|c|c|c|}
\hline & & Mean & SD & Median & p10 & p90 \\
\hline \multirow[t]{3}{*}{ Back-stops } & Limited Liability & 0.52 & 0.50 & 1.00 & 0.00 & 1.00 \\
\hline & Collateral & 0.27 & 0.44 & 0.00 & 0.00 & 1.00 \\
\hline & Number of Collaterals & 0.08 & 0.35 & 0.00 & 0.00 & 0.00 \\
\hline \multirow[t]{7}{*}{ Contract and Lessee Properties } & Hire-purchase & 0.29 & 0.45 & 0.00 & 0.00 & 1.00 \\
\hline & Partial Amortization & 0.51 & 0.50 & 1.00 & 0.00 & 1.00 \\
\hline & Full Payment & 0.20 & 0.40 & 0.00 & 0.00 & 1.00 \\
\hline & Interest Rate & 0.52 & 0.50 & 1.00 & 0.00 & 1.00 \\
\hline & Default Risk & 1.52 & 7.05 & 0.60 & 0.23 & 1.82 \\
\hline & Lease Term & 4.25 & 0.97 & 4.00 & 3.00 & 5.00 \\
\hline & Lending Relationship & 0.60 & 0.49 & 1.00 & 0.00 & 1.00 \\
\hline \multirow[t]{4}{*}{ Default Characteristics } & Asset Value & 0.73 & 0.49 & 0.69 & 0.36 & 1.00 \\
\hline & EAD & 9.79 & 1.28 & 9.92 & 8.07 & 11.24 \\
\hline & Repayment Proportion & 0.29 & 0.29 & 0.28 & -0.08 & 0.70 \\
\hline & Work-out Duration & 5.59 & 1.30 & 5.75 & 3.76 & 7.18 \\
\hline \multirow[t]{6}{*}{ Object Characteristics } & Used Object & 0.30 & 0.46 & 0.00 & 0.00 & 1.00 \\
\hline & Number of Leased Objects & 0.21 & 0.66 & 0.00 & 0.00 & 0.69 \\
\hline & Factory and Office E. & 0.23 & 0.42 & 0.00 & 0.00 & 1.00 \\
\hline & Electronic Devices & 0.02 & 0.15 & 0.00 & 0.00 & 0.00 \\
\hline & Vehicles & 0.57 & 0.49 & 1.00 & 0.00 & 1.00 \\
\hline & Machinery & 0.18 & 0.39 & 0.00 & 0.00 & 1.00 \\
\hline \multirow[t]{4}{*}{ Lessee's Industry } & Construction & 0.19 & 0.39 & 0.00 & 0.00 & 1.00 \\
\hline & Services & 0.46 & 0.50 & 0.00 & 0.00 & 1.00 \\
\hline & Trade & 0.16 & 0.36 & 0.00 & 0.00 & 1.00 \\
\hline & Manufacturing & 0.19 & 0.39 & 0.00 & 0.00 & 1.00 \\
\hline
\end{tabular}

NB: This table reports the descriptive statistics of our exogenous variables. All numbers are based on our 1,156 defaulted contracts. "Mean" ("Std. dev.", "Median") describes the mean (standard deviation, median) of each variable across all observations. "p10" ("p90") refers to the 10th (90th) percentile of the distribution of each variable. Comprehensive variable definitions are provided in Table 2

to inconsistent estimators if ordinary least squares regressions are used to estimate Eq. (3). Since the LGD in leasing is possibly unbounded in the lower domain, we employ a Tobit regression model, set the upper bound equal to 1 , and the lower bound to $-\infty$. The Tobit model is calculated using robust standard errors that are clustered with respect to Contract Type to incorporate correlations within these. Additionally, we include Default Year fixed effects (FEs) for unobserved dynamics over time.

The results are presented in columns (1), (3), and (5) of Table 4. In line with our predictions, we ascertain a significantly negative effect of Collateral and Number of Collaterals on LGD. Beyond the already known effect of Collateral, our analysis reveals that the lessor's opportunity to exploit more than one collateral also has a crucial impact on $L G D$. This is remarkable as the lessor exploits the leased asset and one collateral to satisfy the repayment claim in a first stage. In order to quantify the 
economic relevance, collateralized contracts recover on average about 6.8 percentage points (pp) more (in case of $L G D^{\text {Payment }}$ about $4.0 \mathrm{pp}$ ) than uncollateralized ones, and the logarithmized number of additional collateral lowers $L G D$ by about 9.3 pp (2.8 pp) per unit. Importantly, we show that Limited Liability significantly increases $L G D^{\text {Payment }}$ because companies' wealth is usually dissaved before default.

Switching to Contract and Lessee Properties, the significant coefficients of Default Risk emphasize that the separate consideration of Interest Rate and Default Risk, which our analysis is first to provide, seems to be of great importance when analyzing leasing LGD determinants. In contrast to our predictions, the influence of Default Risk is negative. To provide further insights on the impact of Default Risk on $L G D$, we re-estimate our main regression using the initial rating score, which is defined for values between 100 (best) and 600 (default), with 149 different dummy variables. The marginal effects of all dummy variables are illustrated in Figure A.2 in the online appendix and clearly underpin the negative impact of poor credit ratings on $L G D$. As presented in Table A.5 in the online appendix, the statistical significance of our other determinants in this analysis increases noticeably.

Furthermore, we contribute a number of findings in contradiction to the existing literature. First, Hire-purchase contracts exhibit significantly higher $L G D$ values in comparison to our baseline category Full Payment contracts. Second, leases with higher Interest Rates do not show higher LGDs. Third, Lending Relationship surprisingly leads to an about $3.5 \mathrm{pp}$ higher $L G D$ and about $1.6 \mathrm{pp}$ higher $L G D^{\text {Asset }}$. This result reinforces the argument of Boot (2000) that the lessor is more confident in known lessees and their capabilities. For this reason, it may not refuse continued funding in case of lessee's financial difficulties, and thus, the losses will be particularly high if this lessee finally goes bankrupt.

Default Characteristics strongly contribute to $L G D$ if they are measured by their economic relevance. An increase of $1 \mathrm{pp}$ of the Asset Value leads to a significantly decreasing $L G D$ by about $0.24 \mathrm{pp}\left(L G D^{\text {Asset }}\right.$ by about $0.23 \mathrm{pp}$ ) and an increase by one standard deviation, that amounts to $49 \mathrm{pp}$, lowers $L G D$ by about $12 \mathrm{pp}$ which, in turn, represents about one third of LGD's mean. Additionally, a 1 pp higher Repayment Proportion lowers $L G D$ by about 0.25 pp and an increase by one standard deviation, which yields to $29 \mathrm{pp}$, lessens $L G D$ by about $7 \mathrm{pp}$. Furthermore, a longer Work-out Duration indicates a higher $L G D$ on average. Our results underpin the relevance of the separate analysis of $L G D^{\text {Asset }}$ and $L G D^{\text {Payment }}$, since a longer Workout Duration signals a more challenging asset disposal; therefore a higher $L G D^{\text {Asset }}$ is realized. In contrast, regarding $L G D^{\text {Payment }}$, a longer Work-out Duration also has positive aspects as the lessor profits from the ability to attain repayments from more worthwhile but extensive bankruptcy proceedings.

Focusing on the leased asset, the lessor strongly benefits from the possibility to exploit more than one leased object as Number of Leased Objects significantly lowers $L G D$ and $L G D^{\text {Asset }}$. The economic relevance amounts up to 18 pp for our maximum Number of Leased Objects, which amounts to 6.3 (more than 500 objects). In accordance with the literature, $L G D$ is significantly lower in case of Vehicles as compared to our baseline category Factory and Office Equipment. Contradictory to the literature, Electronic Devices exhibit lower values of $L G D$. Finally, our results predominantly do not reveal a significant impact of the lessee's industry. 
Additionally, we re-estimate our main regression only using variables available in case of loan contracts, that is, without Contract Type, Object Characteristics, and Asset Value. We demonstrate the shortcomings of the leasing LGD explanation when using only the remaining variables, as lease-related information contributes about half of the $R^{2}$ in the regressions on $L G D$ and $L G D^{\text {Asset }}$ (see Table A.6 in the online appendix). Overall, if academics and practitioners look only at those variables which are also available for loan contracts, they disregard major leasing LGD determinants, seriously reducing explanatory power of their models.

\subsection{Spline regression analysis}

As Miller (2016) shows that a non-linear consideration of the explanatory variables significantly enhances the explanatory power of a regression model, when analyzing leasing LGD determinants, we follow the empirical approach presented in Royston and Sauerbrei (2007) and Miller (2016) and estimate linear regression splines for all continuous variables $x_{j}$ in our data set:

$$
L G D\left(x_{j}\right)=a_{j}+b_{j, s} \times x_{j}+\sum_{v=1}^{d} c_{j, v} \times \max \left(0, x_{j}-\gamma_{j, v}\right)+\epsilon_{j},
$$

where $b_{j s}$ and $c_{j v}$ represent the regression coefficients, $\gamma_{i v}$ refers to the regression knots, and $\epsilon_{j}$ is the error term again. The impact of the explanatory variables on $L G D$ is modeled linearly but is allowed to vary across different ranges of $x_{j}{ }^{12}$ Afterwards, we add the non-linear estimates $L G D\left(x_{j}\right)$ in Eq. (3) and re-estimate the adjusted regression equation:

$$
L G D_{i}=\beta_{0}+\sum_{j=1}^{l} \beta_{j}^{1} \times x_{i, j}+\sum_{j=l+1}^{m} \beta_{j}^{2} \times L G D\left(x_{i, j}\right)+\epsilon_{i} .
$$

While $x_{i 1}$ up to $x_{i l}$ represent all explanatory variables which are considered linearly and thus are identically compared to the variables described in Eq. (3), $x_{i, l+1}$ up to $x_{i, m}$ are the regression splines calculated in Eq. (4). In contrast to Miller (2016), we also allow for estimated regression coefficients which are unequal to 1 in case of regression splines in order to enhance the model's estimation capabilities and to account for non-linearities within the Tobit model. ${ }^{13}$

We present the results in columns (2), (4), and (6) of Table 5. Focusing on the explanatory power of the regression models, $R^{2}$ increases by about 6 and $7 \%$ in columns (2) and (4), respectively, whereas the model of $L G D^{\text {Payment }}$ does not significantly benefit from using regression splines. This is also reflected by the number of

\footnotetext{
12 Following Royston and Sauerbrei (2007), we require a significance level of 5\% to include the nonlinear relations in Eq. (5). If using a 1\% significance level as proposed by Miller (2016), the estimation procedure rarely provides any non-linear influence.

${ }_{13}$ We also calculate all estimates without regression coefficients of $L G D\left(x_{i, j}\right)$. While the $R^{2}$ is only about half of the value when applying regression coefficients and is also considerably lower than in the linear estimation procedure, the regression results remain qualitatively unaffected with the exception of the contract types.
} 
non-linearly considered variables. While Asset Value, EAD, Repayment Proportion, and Work-out Duration are modeled non-linearly in case of $L G D$, only Interest Rate non-linearly affects $L G D^{\text {Payment }}$. Analyzing the influence of single determinants, Asset Value does surprisingly not exhibit a significant impact on $L G D$ and $L G D^{\text {Asset }}$, while Repayment Proportion and Work-out Duration are significant LGD determinants further on. As shown by Figures A.3 through A.6, the non-linear consideration of the respective variables also modifies the direction of the determinants' impact to some extent. On the one hand, the regression spline of Repayment Proportion exhibits a predominantly negative relation to Repayment Proportion and, thus, the positive sign of Repayment Proportion in the regression results is in line with the finding in Sect. 4.1. On the one hand, the impacts of EAD and Work-out Duration change considerably depending on the level of the respective variable. Finally, the majority of the determinants that are still considered linearly exhibit coefficients which are very similar to those in the linear model.

\subsection{Variable selection procedure}

Next, we apply the variable selection procedure proposed by Frank and Goyal (2009) and evaluate the determinants that are essential influence factors of $L G D$. Therefore, we use the Bayesian information criterion (BIC) and the Akaike information criterion (AIC), which are defined as:

$$
\begin{aligned}
& \mathrm{BIC}=-2 \times \log \text {-likelihood }+\mathrm{P} \times \log (\mathrm{N}) \\
& \text { and } \mathrm{AIC}=-2 \times \log \text {-likelihood }+2 \times \mathrm{P},
\end{aligned}
$$

where $\mathrm{P}$ (respectively $\mathrm{N}$ ) represents the number of parameters (observations). BIC and AIC decrease with a higher (log-)likelihood and increase with a higher number of parameters. As a result, lower values of BIC and AIC signal an enhanced variable selection. Since $\log (\mathrm{N})$ is greater than 2 in our study, BIC penalizes a high number of variables stronger than AIC.

In order to derive our main influence factors, we begin with the estimation of our regression model on $L G D$ as displayed in Eq. (3) and report the corresponding (cumulative) $R^{2}$, BIC, and AIC in columns (4), (5), and (6) of the last row in Table 5. After identifying the variable with the lowest $t$-statistic, we run a separate one-variable regression only using this variable as the single exogenous variable and report our results in columns (1), (2), and (3) of the same row. Then the variable is removed from the model, and we need to re-estimate the model. The results of this new estimation are reported in columns (4), (5), and (6) of the next higher row in the table. Again, we search for the variable exhibiting the lowest t-statistic, estimate a separate one-variable regression only including this variable, and report the results in columns (1), (2), and (3) of the penultimate row. We iterate this process until only a single variable remains at the top of the table: Work-out Duration. Since they promise the optimal selection of exogenous variables, we look for the specifications with the lowest BIC and AIC. Additionally, in order to make sure that our results are not driven by coincidences, Frank and Goyal (2009) propose to re-run the analysis for subsamples. Therefore, we randomly 
choose $50 \%$ of the observations from our data set to create a subsample. This step is conducted ten times, and thus, we get ten different subsamples. For every subsample, we re-run the analysis separately. Columns (7) and (8) illustrate the percentages of subsample analyses wherein the respective determinant is part of the optimal set of exogenous variables. Following Frank and Goyal (2009), we mainly focus on BIC and only consider variables that are confirmed by more than $50 \%$ of the subsample estimations.

The major LGD determinants include Work-out Duration (+), Repayment Proportion (-), Number of Collaterals (-), Number of Leased Objects (-), Hire-purchase contracts (+), Lease Term (+), Asset Value (-), and Object Type Vehicles (-). Largely, these main impact factors are the most significant variables from our regression, as discussed in Sect. 4.1. In line with our predictions and the results in Sect. 4.1, the removal of Asset Value or Repayment Proportion very clearly increases the BIC, thus indicating that these variables provide essential value added. This is also evident from observed Own $R^{2}$, which incorporates the $R^{2}$ of the one-variable regressions. As AIC penalizes a large number of exogenous variables less severely, Lending Relationship, the Object Types Machinery and Electronic Devices, Collateral, Limited Liability, and Lessee's Industry Trade also form part of the main $L G D$ determinants if the selection process hinges on AIC. Both models acknowledge the minor importance of Lessee's Industry, EAD, Used Object, and Interest Rate.

\subsection{Macroeconomic environment regression analysis}

The LGD of loans and leases is expected by the regulator to be sensitive to the macroeconomic environment. Therefore, lessors that use own IRBA risk assessments have to estimate the LGD in economic downturns, the so-called "Downturn LGD" (European Banking Authority 2019). Hartmann-Wendels and Honal (2010) reveal a negative impact of the macroeconomic environment on the LGD, especially arising from lower leased asset utilization proceeds. Miller (2016) shows a significant but mixed impact of this influence factor on the LGD, which is especially pronounced when analyzing LGD determinants at contract inception.

We re-estimate Equation (3), additionally controlling for the GDP growth rate in the year before the contract defaulted. As otherwise the default year FEs capture the macroeconomic environment, we omit them in this regression. Our results are summarized in Table 6 and clearly indicate a negative impact of $G D P$ on $L G D$ and $L G D^{\text {Payment }}$. Therefore, we underpin the negative impact of the macroeconomic environment on $L G D$ as shown by Hartmann-Wendels and Honal (2010), but in contrast to this study, we show significant results on $L G D^{\text {Payment }}$, but no significance in case of $L G D^{\text {Asset }}$.

\subsection{Explanation of particularly high and low LGDs}

As indicated by the modal values around zero and one in Fig. 1, lessors repeatedly recover the entire outstanding EAD (and sometimes even more) of defaulted leases or almost nothing. To provide further details of these particular realizations of $L G D$, we introduce the dummy variable $L G D^{+}\left(L G D^{-}\right)$, which is equal to one if $L G D$ is exactly 1 (is equal to or lower than 0 ) and zero otherwise. Additionally, 
since the lessor is only able to generate revenues from asset utilization or repayments for a part of the contracts, we define Utilization $^{+}$and Payment ${ }^{+}$, which are equal to 1 if the lessor receives anything from the asset utilization or any repayments, that is, $L G D^{\text {Asset }}$ and $L G D^{\text {Payment }}$ are lower than 1 . From lessors' perspective, the results of this analysis are of crucial importance, since they have to decide on their work-out intensity and effort in general as well as regarding a specific contract in default. But, as this effort is costly, expectations about whether asset utilization proceeds or any repayments can be obtained facilitate the lessors' optimization of the recovery process (Miller and Töws 2018). Therefore, we re-estimate Equation (3) by running separate Probit regressions with the endogenous variables $L_{G} D^{+}, L_{G}{ }^{-}$, Utilization ${ }^{+}$, and Payment ${ }^{+}$and present the results in Table 7.

According to our findings above, the coefficient of Limited Liability is significantly negative in specifications (1), (3), and (4). Providing Collateral and a higher Number of Collaterals constitute additional sources of repayments, and therefore, the probability of obtaining a low $L G D$ value as well as of obtaining repayments significantly increases. Additionally, Hire-purchase contracts exhibit a significantly higher probability of having high $L G D$ values (2), whereas the probability of receiving asset utilization proceeds is significantly lower (3). Opposite to our results in Sect. 4.1, higher Asset Value predominantly leads to significantly increased probabilities of a high value of $L G D$ and a decreased probability of asset utilization proceeds. However, with respect to the probability of a low value of $L G D$, Asset Value has a positive impact. Additionally, a longer Work-out Duration lowers the probability of receiving utilization proceeds and increases the probability of payments from lessee or collateral.

\subsection{Explanation of default and contract choice}

In this section, we provide evidence on lease contracts' $P D$ as a second crucial leasing credit risk component (e.g., Pfister et al. 2015). As a new research topic, we additionally establish first indications on lessors' and lessees' choice of certain Contract Types. Surprisingly, to the best of our knowledge, no study has been conducted so far on lease contract choice. We apply the event of default and our three dummy variables Full Payment, Partial Amortization, and Hire-purchase as endogenous variables. We restrict the exogenous variables used in our first regression (Equation (3)) to those determinants, which are known at contract conclusion. Therefore, we forego Default Characteristics and Default Year FEs and additionally control for Lease Amount and Origination Year FEs.

Table 8 depicts the results on $P D$ derived from estimations with and without $C o n-$ tract Type (in columns (1) and (2)), since different contract types imply differential payment conditions and, thus, may affect lessee's $P D$. Economically reasonable, the majority of directions of our significant coefficients differ from those in our regressions on $L G D$. If we assume a constant credit risk limit per contract as preferred by the bank's risk-taking strategy (e.g., De Laurentis and Mattei 2009), that is, a 


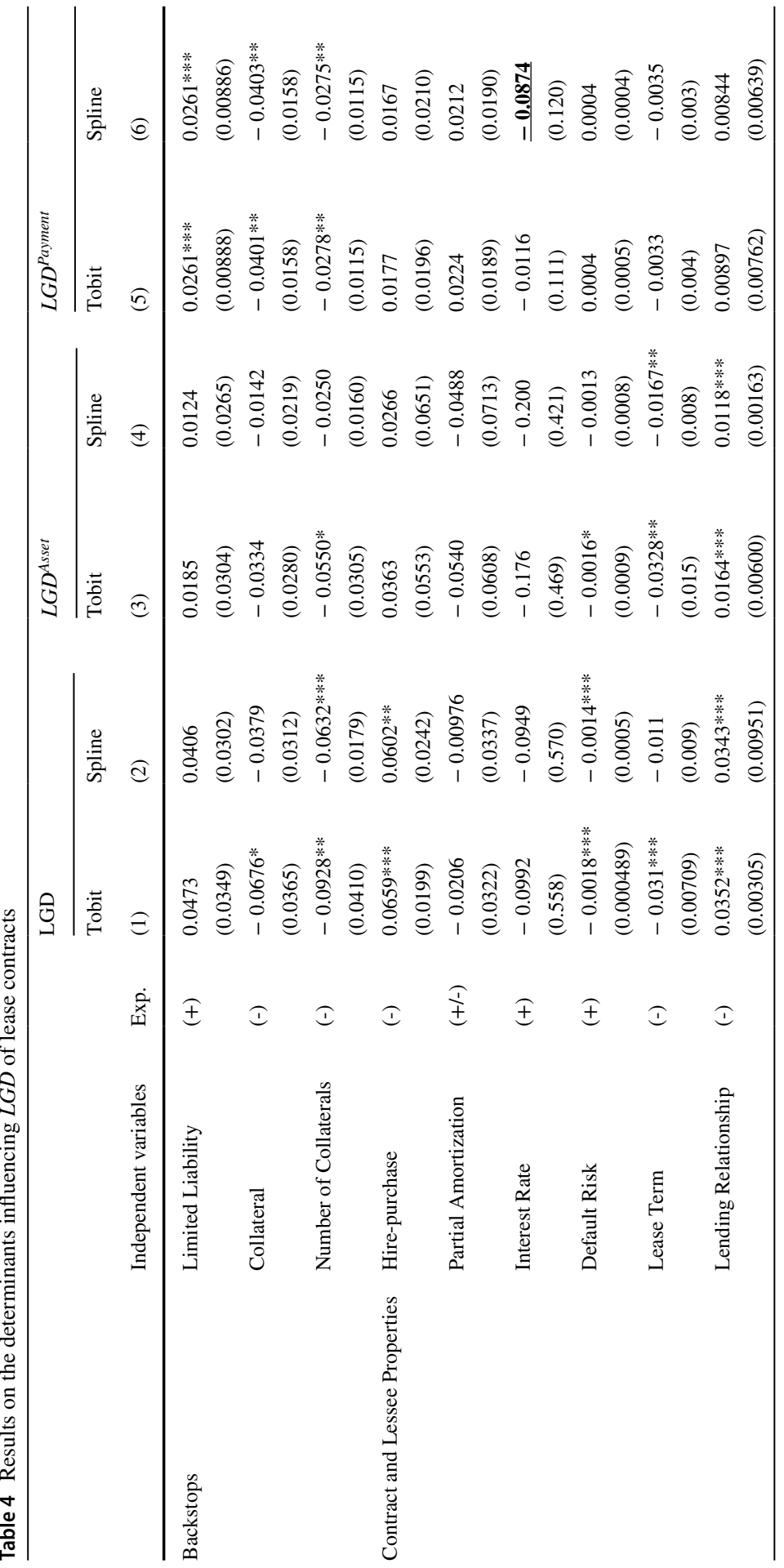




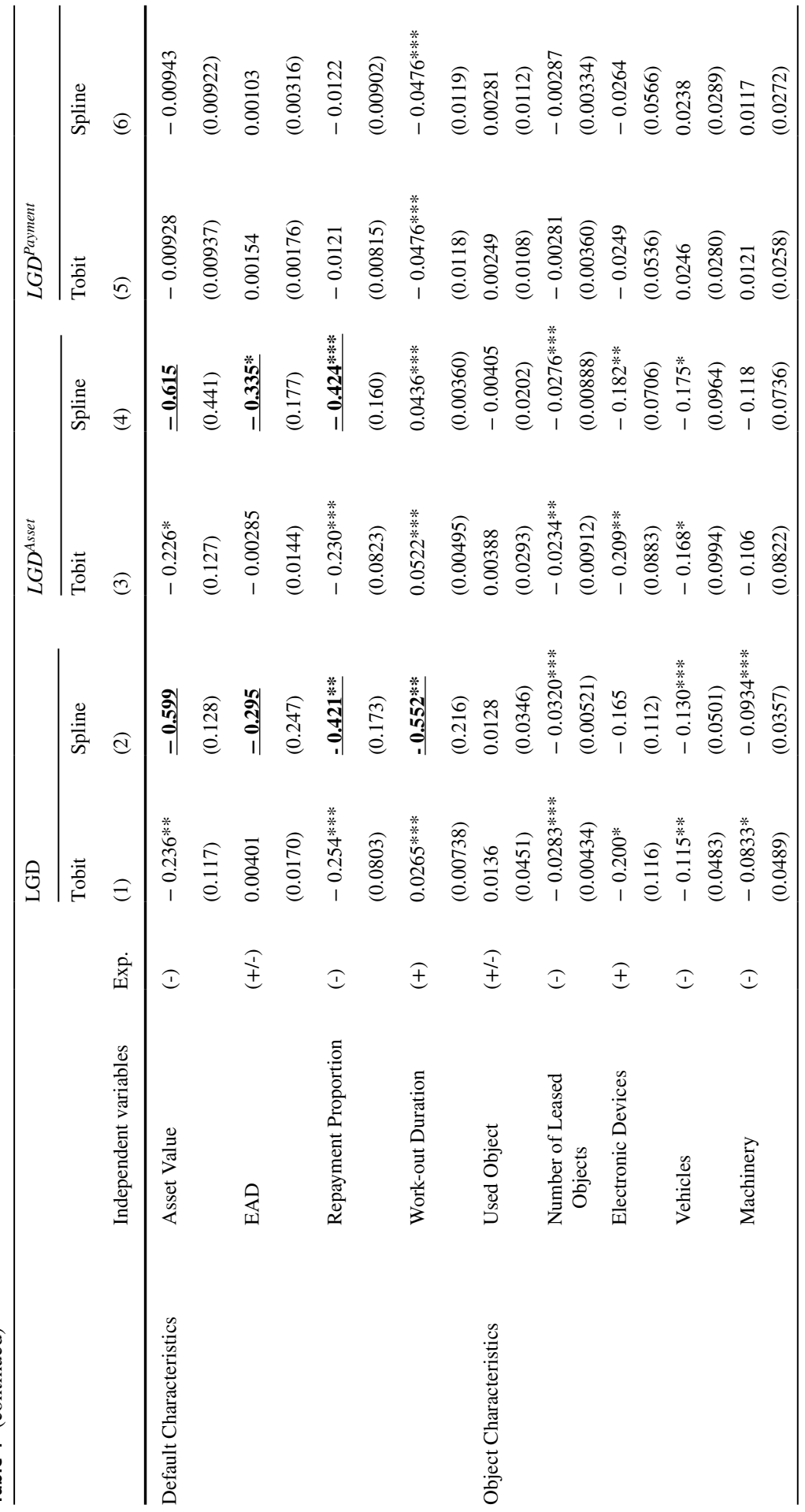




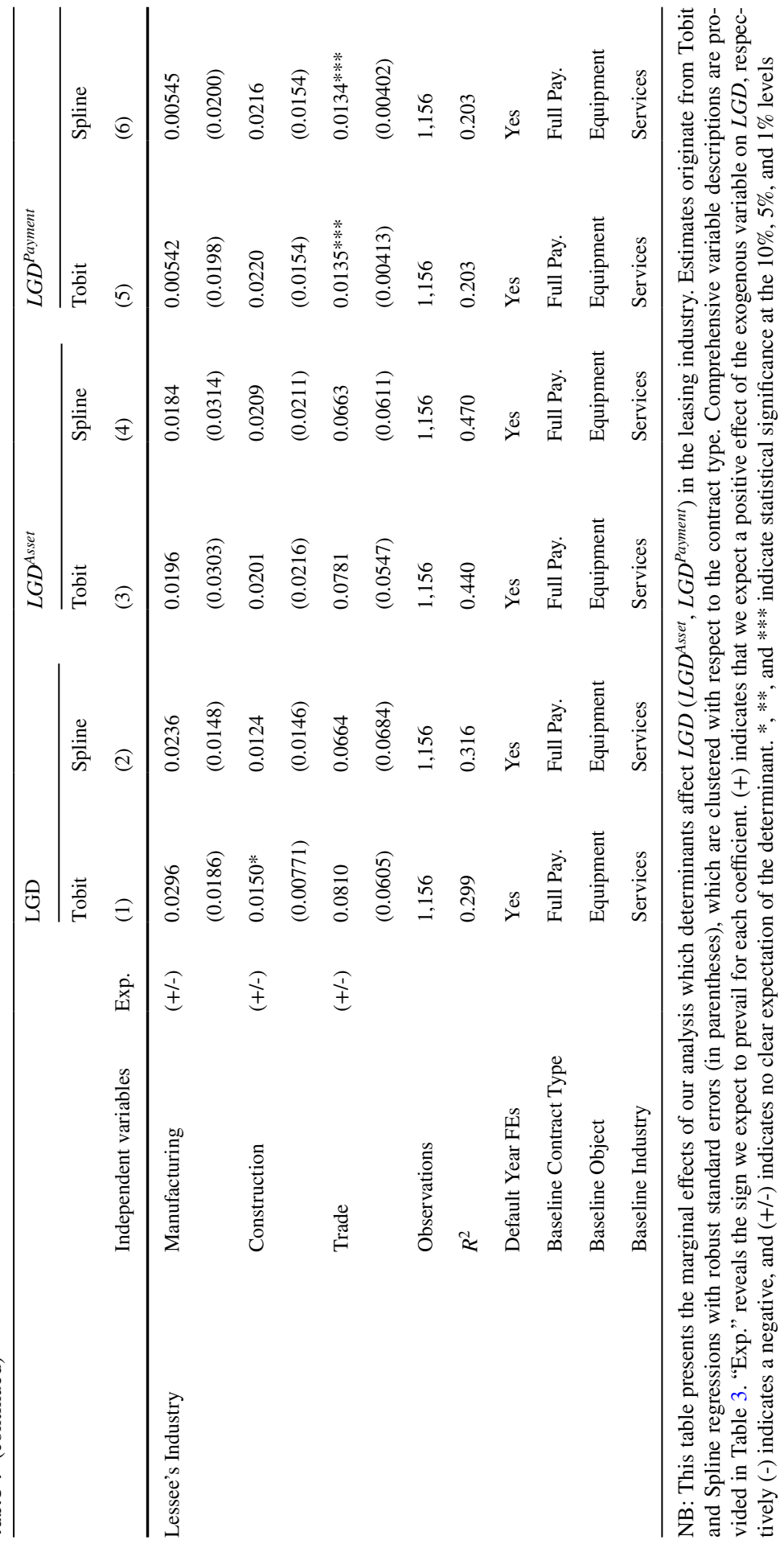


constant expected value of PD's and LGD's product, variables which increase the LGD are supposed to lower lease contracts' PD, on average.

Exemplary, in line with the literature on loan PD (e.g., Boot and Thakor 1994; Jiménez and Saurina 2004), the lessor requires additional collateral if moral hazard problems are presumed and, consequently, $P D$ is found to be higher. In a similar vein, Hire-purchase contracts seem to comprise a lower default risk. Focusing on the Default Risk, we show its highly significant positive effect on $P D$ indicating a meaningful explanatory power of the external rating in our data set. Considering the absolute values of the variables' scattering, this also exceeds the effect of Interest Rate, which, however, is negative.

The results on the choice of Contract Type will be interpreted cautiously as we are aware of the possibility that this choice may also affect - albeit to some extentsome (exogenous) variables in our regression. To begin with, we can observe that Object Type and Lessee's Industry are major impact factors of contract choice. Switching to the Backstops and Contract and Lessee Properties, on average, large contracts to more risky yet better-known lessees without limited liability are granted as Hire-purchase contracts. Illuminating a noteworthy effect of Hire-purchase on $L G D$, this result seems to be counterintuitive. However, as shown above, taking a lower PD of Hire-purchase contracts into account, the lessor's behavior may be in line with a constant contract credit risk. These results once again emphasize the particularity of credit risk in the leasing industry as specific Object and Lessee's Characteristics are accompanied by differential leasing Contract Types. This fact may alter the economic mechanism of well-known loan risk determinants when explaining leasing risk.

\section{Robustness checks}

We conduct several tests to reinforce the economic and econometric robustness of our results. First, realized values of $L G D\left(L G D^{\text {Asset }}, L G D^{\text {Payment }}\right)$ are apparently only observable in case of lease default. As defaults and LGDs are often assumed to be correlated, the estimated parameters might be biased (e.g., Heckman 1979; Rösch and Scheule 2014). Therefore, we estimate a two-stage Heckman selection model (e.g., Bade et al. 2011; Krüger et al. 2018) and correct the parameter estimates of our $L G D\left(L G D^{\text {Asset }}, L G D^{\text {Payment }}\right)$ determinants. For this purpose, as the first step, we calculate our default regression (see Sect. 4.6) for estimating the selection equation, which identically applies to $L G D, L G D^{\text {Asset }}$, and $L G D^{\text {Payment }}{ }^{14}$ As a second step, we estimate three outcome equations (one for each $L G D, L G D^{\text {Asset }}$, and $L G D^{\text {Payment }}$ ), which are equal to Equation (3) in Sect. 4.1. The results are presented in Table A.7 in the online appendix and strengthen our findings in Sect. 4 as the results remain

\footnotetext{
14 This is reasonable as the lessor is theoretically able to receive liquidation proceeds or repayments in case of lessee's default independently of the fact whether there are actual liquidation proceeds or repayments. For all defaulted contracts, $L G D^{\text {Asset }}$ and $L G D^{\text {Payment }}$ are appropriately calculable and economically reasonable (and may be 1 in case of no actual liquidation proceeds or repayments), clearly distinguishable from those lease contracts, which do not default.
} 
qualitatively the same, while significance levels even increase (see, e.g., Asset Value).

Second, banks might consider their expectations for the LGD when determining a contract's interest rate. To address this issue, we run a two-stage instrumental variable (iv) regression model replacing Interest Rate. In the first stage, we use Interest Rate as endogenous variable and add the average interest rate (Av. Interest Rate) within a respective group of contracts exhibiting the same combination of contract type, leased object type, and lessee's industry as regressor (instrument) estimating InterestRate. ${ }^{15}$ The results are presented in Table A.8 in the online appendix. Again, we estimate only one first stage regression model since the potential issues as well as the prediction of InterestRate does not differ across our three LGD measures. In the second stage, we use InterestRate instead of Interest Rate as $L G D$ ( $L G D^{\text {Asset }}$, $L G D^{\text {Payment }}$ ) determinant. As Table A.10 in the online appendix shows, the results of the iv regression model support the validity of our findings.

Third, Hartmann-Wendels et al. (2014) emphasize the importance of different information sets available at the time of contracting and at the time of lessee's default. Additionally, Default Characteristics are major determinants of the LGD, but we are aware that the recovery process and the LGD could also affect these. In order to provide further insights and clarifications on this issue, we re-estimate our regression of Sect. 4.1 using the variables of the default estimation in Sect. 4.6, that is, we estimate the regression without Default Characteristics and Default Year FEs while including Lease Amount and Origination Year FEs. In comparison to our main models, the results predominantly remain unchanged, as displayed in Table A.11 in the online appendix.

Fourth, we take the observations that exhibit surprisingly low values of $L G D$, $\mathrm{LGD}^{\text {Asset }}$, and LGD ${ }^{\text {Payment }}$ into account, winsorize these variables at the $1 \%$ level, and re-estimate our main analysis. Our results remain qualitatively unchanged (see Table A.12 in the online appendix).

Fifth, in order to validate econometric robustness, we reconsider standard error clustering and use clustered standard errors with respect to lessees as opposed to Contract Types. Even though we observe only about 1.5 contracts per lessee on average, within lessee correlations are conceivable. As displayed in Table A.13 in the online appendix, our results do not change substantially.

Sixth, it may be argued that lessees from different industries use the same object differently; thus, we additionally control for the interaction effect between Object Type and Lessee's Industry in Table A.4 in the online appendix. This increases $R^{2}$, but we still find the same main determinants of $L G D$ as compared to our main analysis.

\footnotetext{
15 In an additional analysis, we re-estimate our iv regression model using the average interest rate within the groups of the same leased object type-lessee's industry combinations. While the statistical significance of this instrument decreases in the first stage regression (t-statistic: 4.43), the results of the second stage regressions remain qualitatively unchanged (see Table A.9 in the online appendix).
} 
Table 5 Results on the variable selection procedure of leasing LGD determinants

\begin{tabular}{|c|c|c|c|c|c|c|c|c|}
\hline Variable & Coef. Est. & t-stat & Own $R^{2}$ & $\begin{array}{l}\text { Cumulative } \\
R^{2} \\
\text { (4) }\end{array}$ & $\mathrm{BIC}$ & AIC & $\begin{array}{l}\text { Group } \\
\text { BIC \% } \\
\text { (7) }\end{array}$ & $\begin{array}{l}\text { Group } \\
\text { AIC\% } \\
(8)\end{array}$ \\
\hline $\begin{array}{l}\text { Work-out Dura- } \\
\text { tion }\end{array}$ & 0.028 & 6.09 & 0.02 & 0.02 & 1193.98 & 1153.55 & 80 & 100 \\
\hline $\begin{array}{l}\text { Repayment } \\
\text { Proportion }\end{array}$ & -0.341 & -3.82 & 0.10 & 0.12 & 1086.42 & 1040.95 & 100 & 100 \\
\hline $\begin{array}{l}\text { Lending Rela- } \\
\text { tionship }\end{array}$ & 0.022 & 1.07 & 0.00 & 0.12 & 1089.23 & 1038.70 & 50 & 70 \\
\hline $\begin{array}{l}\text { Number of Col- } \\
\text { laterals }\end{array}$ & -0.067 & -1.81 & 0.00 & 0.13 & 1086.73 & 1031.15 & 90 & 100 \\
\hline $\begin{array}{c}\text { Number of } \\
\text { Leased } \\
\text { Objects }\end{array}$ & -0.242 & -1.92 & 0.00 & 0.13 & 1092.62 & 1031.99 & 60 & 80 \\
\hline Hire-purchase & 0.052 & 7.33 & 0.00 & 0.14 & 1093.79 & 1028.11 & 80 & 80 \\
\hline Vehicles & -0.015 & -0.61 & 0.00 & 0.15 & 1089.46 & 1018.72 & 90 & 100 \\
\hline Lease Term & 0.005 & 0.74 & 0.00 & 0.15 & 1095.50 & 1019.71 & 60 & 70 \\
\hline Asset Value & -0.241 & -1.79 & 0.14 & 0.26 & 970.15 & 889.31 & 90 & 100 \\
\hline Machinery & 0.312 & 1.10 & 0.00 & 0.27 & 970.26 & 884.36 & 40 & 80 \\
\hline $\begin{array}{c}\text { Electronic } \\
\text { Devices }\end{array}$ & -0.136 & -1.87 & 0.00 & 0.28 & 965.92 & 874.97 & 30 & 70 \\
\hline Default Risk & 0.000 & 0.47 & 0.00 & 0.28 & 971.53 & 875.52 & 30 & 50 \\
\hline Collateral & 0.044 & -1.67 & 0.00 & 0.28 & 973.76 & 872.71 & 30 & 60 \\
\hline $\begin{array}{l}\text { Limited Liabil- } \\
\text { ity }\end{array}$ & 0.027 & 1.09 & 0.00 & 0.29 & 972.85 & 866.74 & 10 & 70 \\
\hline Trade & 0.066 & 1.61 & 0.00 & 0.30 & 970.51 & 859.35 & 40 & 60 \\
\hline Construction & 0.015 & 0.91 & 0.00 & 0.30 & 977.49 & 861.28 & 0 & 20 \\
\hline Manufacturing & 0.007 & 0.40 & 0.00 & 0.30 & 983.23 & 861.96 & 0 & 20 \\
\hline $\begin{array}{l}\text { Partial Amorti- } \\
\text { zation }\end{array}$ & -0.035 & -1.86 & 0.00 & 0.30 & 990.10 & 863.78 & 20 & 20 \\
\hline EAD & 0.036 & 2.92 & 0.02 & 0.30 & 996.88 & 865.51 & 0 & 10 \\
\hline Used Object & 0.037 & 0.88 & 0.00 & 0.30 & 1003.47 & 867.05 & 0 & 10 \\
\hline Interest Rate & -0.233 & -0.60 & 0.00 & 0.30 & 1010.35 & 868.88 & 0 & 20 \\
\hline
\end{tabular}

NB: This table presents the results of the variable selection procedure provided by Frank and Goyal (2009). "Coef. Est.", "t-stat", and "Own $R^{2}$ " in columns (1), (2), and (3) contain the coefficient estimates, t-statistics and the $R^{2} \mathrm{~s}$ of the one-variable regressions examining only the exogenous variable of the respective row in a Tobit regression. "Cumulative $R^{2}$ ", "BIC", and "AIC" in columns (4), (5), and (6) show the regression results using the variable, which is located in the respective row and all variables from the rows above. Columns (7) and (8) provide the percentage number of ten subsample analyses in which the variable has proven to be robust against observation selection biases. The optimal variable selection is constituted by the variables above the minimum BIC (AIC), which exhibit more than 50\% confirmation and displayed by the dashed lines. Estimates originate from Tobit regressions with default year fixed effects and robust standard errors, which are clustered with respect to the contract type. Comprehensive variable descriptions are provided in Table 3 
Table 6 Results on the determinants influencing the LGD of lease contracts (controlling for GDP)

\begin{tabular}{|c|c|c|c|c|c|}
\hline & $\begin{array}{l}\text { Independent } \\
\text { variables }\end{array}$ & Exp. & $\begin{array}{l}\text { LGD } \\
\text { (1) }\end{array}$ & $\begin{array}{l}L G D^{\text {Asset }} \\
\text { (2) }\end{array}$ & $\begin{array}{l}\text { LGD Payment } \\
\text { (3) }\end{array}$ \\
\hline \multirow[t]{3}{*}{ Backstops } & $\begin{array}{l}\text { Limited } \\
\text { Liability }\end{array}$ & $(+)$ & $\begin{array}{l}0.0440 \\
(0.0383)\end{array}$ & $\begin{array}{l}0.0171 \\
(0.0329)\end{array}$ & $\begin{array}{l}0.0263 * * * \\
(0.00905)\end{array}$ \\
\hline & Collateral & $(-)$ & $\begin{array}{l}-0.0610^{*} \\
(0.0330)\end{array}$ & $\begin{array}{l}-0.0291 \\
(0.0258)\end{array}$ & $\begin{array}{l}-0.0371 * * * \\
(0.0142)\end{array}$ \\
\hline & $\begin{array}{l}\text { Number of } \\
\text { Collaterals }\end{array}$ & $(-)$ & $\begin{array}{l}-0.0922^{* *} \\
(0.0375)\end{array}$ & $\begin{array}{l}-0.0544 * * \\
(0.0265)\end{array}$ & $\begin{array}{l}-0.0265^{* *} \\
(0.0131)\end{array}$ \\
\hline \multirow[t]{6}{*}{$\begin{array}{l}\text { Contract and Lessee } \\
\text { Properties }\end{array}$} & Hire-purchase & $(-)$ & $\begin{array}{l}0.0632 * * * \\
(0.0183)\end{array}$ & $\begin{array}{l}0.0351 \\
(0.0537)\end{array}$ & $\begin{array}{l}0.0171 \\
(0.0209)\end{array}$ \\
\hline & $\begin{array}{l}\text { Partial Amorti- } \\
\text { zation }\end{array}$ & $(+/-)$ & $\begin{array}{l}-0.0229 \\
(0.0287)\end{array}$ & $\begin{array}{l}-0.0546 \\
(0.0576)\end{array}$ & $\begin{array}{l}0.0236 \\
(0.0192)\end{array}$ \\
\hline & Interest Rate & $(+)$ & $\begin{array}{l}-0.136 \\
(0.576)\end{array}$ & $\begin{array}{l}-0.181 \\
(0.521)\end{array}$ & $\begin{array}{l}0.0114 \\
(0.114)\end{array}$ \\
\hline & Default Risk & $(+)$ & $\begin{array}{l}-0.00167 * * * \\
(0.000576)\end{array}$ & $\begin{array}{l}-0.00163 * \\
(0.000852)\end{array}$ & $\begin{array}{l}0.000306 \\
(0.000469)\end{array}$ \\
\hline & Lease Term & $(-)$ & $\begin{array}{l}-0.0308 * * * \\
(0.00627)\end{array}$ & $\begin{array}{l}-0.0326 * * \\
(0.0141)\end{array}$ & $\begin{array}{l}-0.00264 \\
(0.00440)\end{array}$ \\
\hline & $\begin{array}{l}\text { Lending Rela- } \\
\text { tionship }\end{array}$ & $(-)$ & $\begin{array}{l}0.0370 * * * \\
(0.00243)\end{array}$ & $\begin{array}{l}0.0175 * * * \\
(0.00647)\end{array}$ & $\begin{array}{l}0.00949 \\
(0.00774)\end{array}$ \\
\hline \multirow[t]{4}{*}{ Default Characteristics } & Asset Value & $(-)$ & $\begin{array}{l}-0.234 * \\
(0.120)\end{array}$ & $\begin{array}{l}-0.224 * \\
(0.128)\end{array}$ & $\begin{array}{l}-0.00784 \\
(0.00749)\end{array}$ \\
\hline & EAD & $(+/-)$ & $\begin{array}{l}0.00349 \\
(0.0164)\end{array}$ & $\begin{array}{l}-0.00303 \\
(0.0137)\end{array}$ & $\begin{array}{l}0.000911 \\
(0.00246)\end{array}$ \\
\hline & $\begin{array}{l}\text { Repayment } \\
\text { Proportion }\end{array}$ & $(-)$ & $\begin{array}{l}-0.253^{* * *} \\
(0.0817)\end{array}$ & $\begin{array}{l}-0.230 * * * \\
(0.0816)\end{array}$ & $\begin{array}{l}-0.0141 \\
(0.00973)\end{array}$ \\
\hline & $\begin{array}{l}\text { Work-out } \\
\text { Duration }\end{array}$ & $(+)$ & $\begin{array}{l}0.0248 * * \\
(0.00981)\end{array}$ & $\begin{array}{l}0.0518 * * * \\
(0.00833)\end{array}$ & $\begin{array}{l}-0.0446^{* * *} \\
(0.0137)\end{array}$ \\
\hline \multirow[t]{5}{*}{ Object Characteristics } & Used Object & $(+/-)$ & $\begin{array}{l}0.0132 \\
(0.0464)\end{array}$ & $\begin{array}{l}0.00361 \\
(0.0306)\end{array}$ & $\begin{array}{l}0.00195 \\
(0.0116)\end{array}$ \\
\hline & $\begin{array}{c}\text { Number of } \\
\text { Leased } \\
\text { Objects }\end{array}$ & $(-)$ & $\begin{array}{l}-0.0269 * * * \\
(0.00467)\end{array}$ & $\begin{array}{l}-0.0227 * * \\
(0.00976)\end{array}$ & $\begin{array}{l}-0.00262 \\
(0.00356)\end{array}$ \\
\hline & $\begin{array}{c}\text { Electronic } \\
\text { Devices }\end{array}$ & $(+)$ & $\begin{array}{l}-0.210 * \\
(0.113)\end{array}$ & $\begin{array}{l}-0.214 * * \\
(0.0842)\end{array}$ & $\begin{array}{l}-0.0288 \\
(0.0536)\end{array}$ \\
\hline & Vehicles & $(-)$ & $\begin{array}{l}-0.116^{* * *} \\
(0.0440)\end{array}$ & $\begin{array}{l}-0.168 * \\
(0.0961)\end{array}$ & $\begin{array}{l}0.0229 \\
(0.0314)\end{array}$ \\
\hline & Machinery & $(-)$ & $\begin{array}{l}-0.0875^{* *} \\
(0.0438)\end{array}$ & $\begin{array}{l}-0.108 \\
(0.0769)\end{array}$ & $\begin{array}{l}0.00907 \\
(0.0294)\end{array}$ \\
\hline
\end{tabular}


Table 6 (continued)

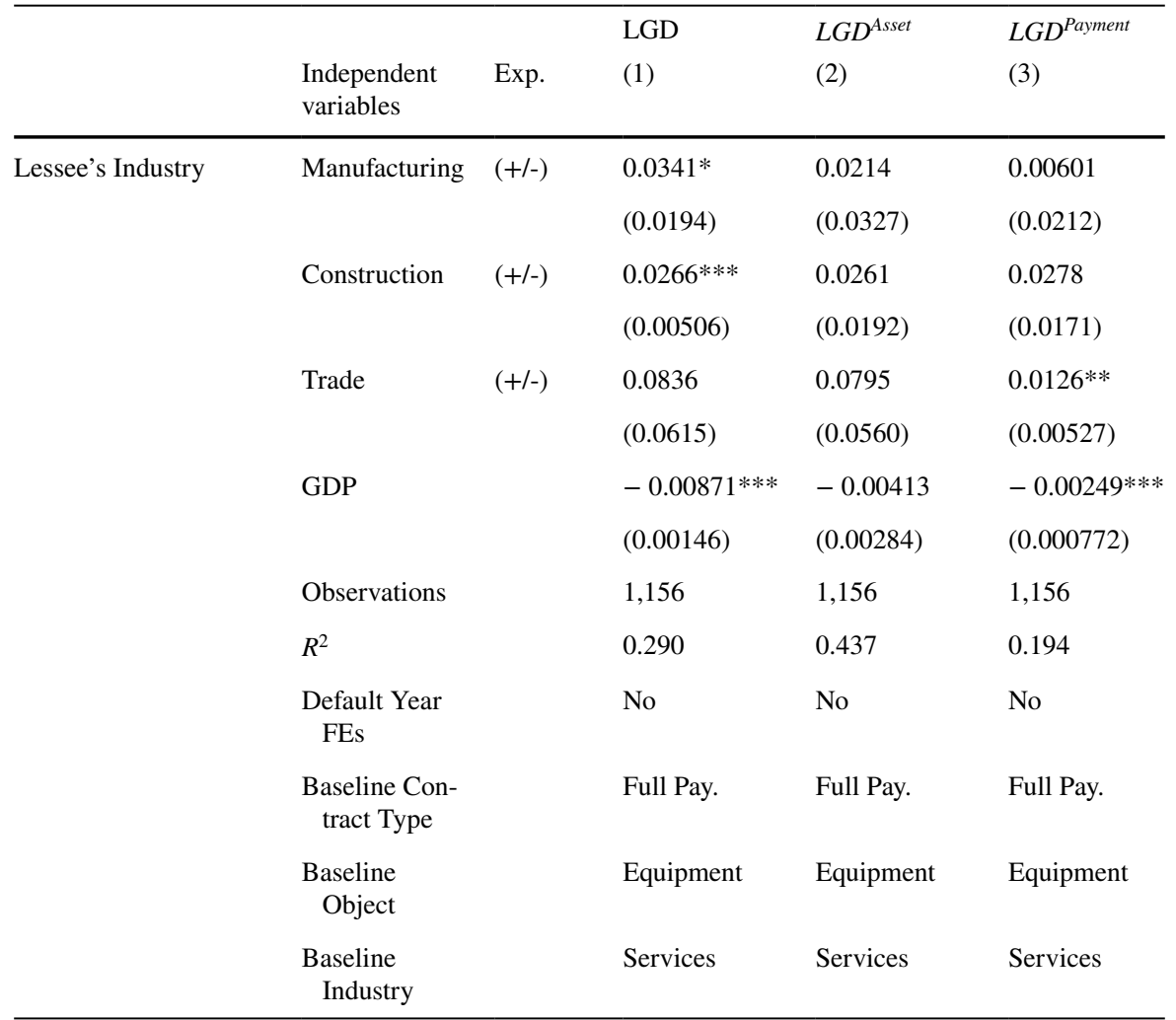

NB: This table presents the average marginal effects of our analysis which determinants affect $L G D$ $\left(L G D^{\text {Asset }}, L G D^{\text {Payment }}\right.$ ) in the leasing industry, additionally analyzing the impact of the macroeconomic environment. Estimates originate from Tobit regressions with robust standard errors (in parentheses), which are clustered with respect to the contract type. Comprehensive variable descriptions are provided in Table 3 in the main body of the paper. "Exp." reveals the sign we expect to prevail for each coefficient. $(+)$ indicates that we expect a positive effect of the exogenous variable on $L G D$, respectively (-) indicates a negative, and (+/-) indicates no clear expectation of the determinant. *,**, and *** indicate statistical significance at the $10 \%, 5 \%$, and $1 \%$ levels

Seventh, to further strengthen our results on the variable selection procedure proposed by Frank and Goyal (2009), we additionally estimate a backward selection model. In this model, the regression displayed in Equation (3) is iteratively re-estimated, and in each iteration, the explanatory variable obtaining least significance is removed from the model if its significance level is above $10 \%$. The results are presented in Table A.15 and clearly reinforce our findings. 


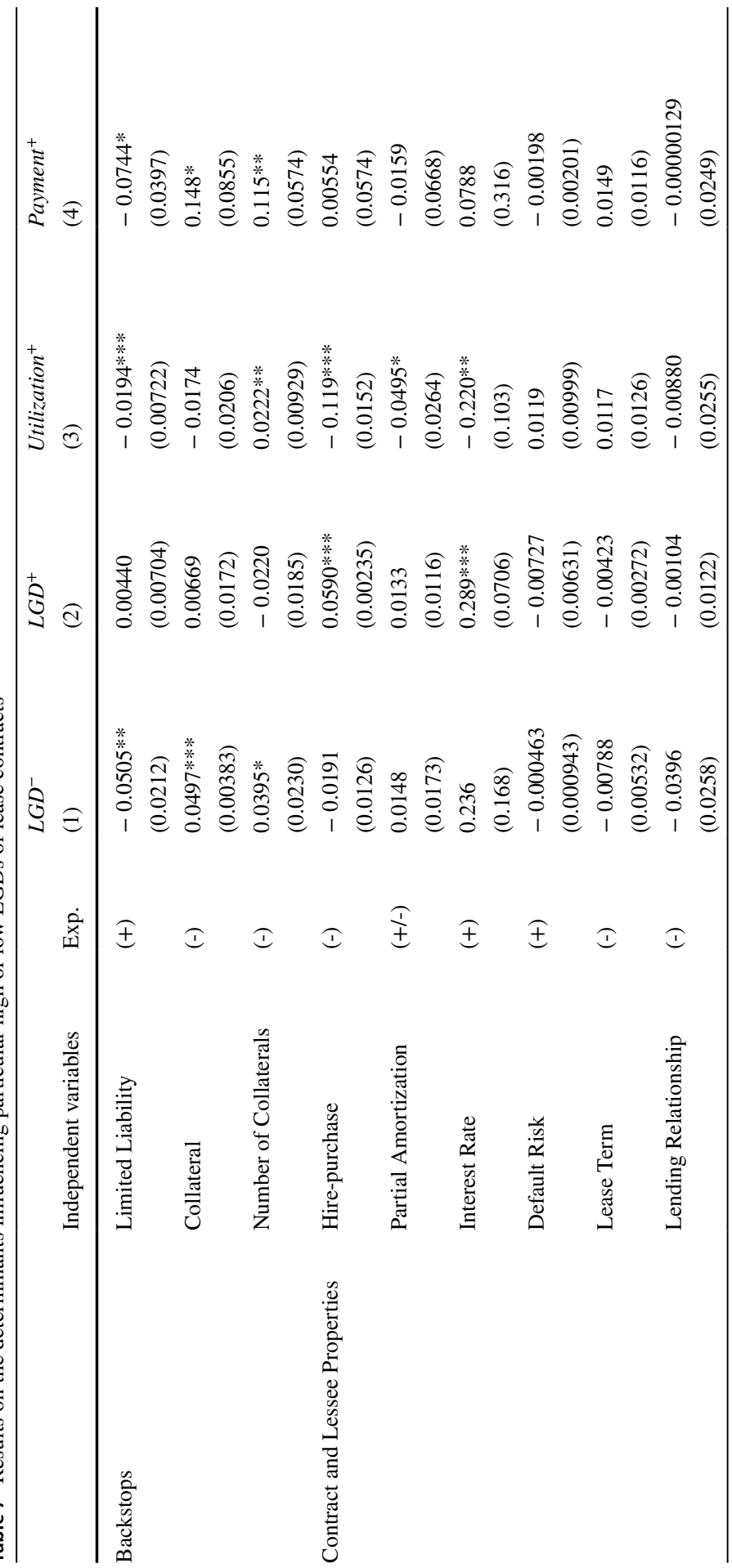




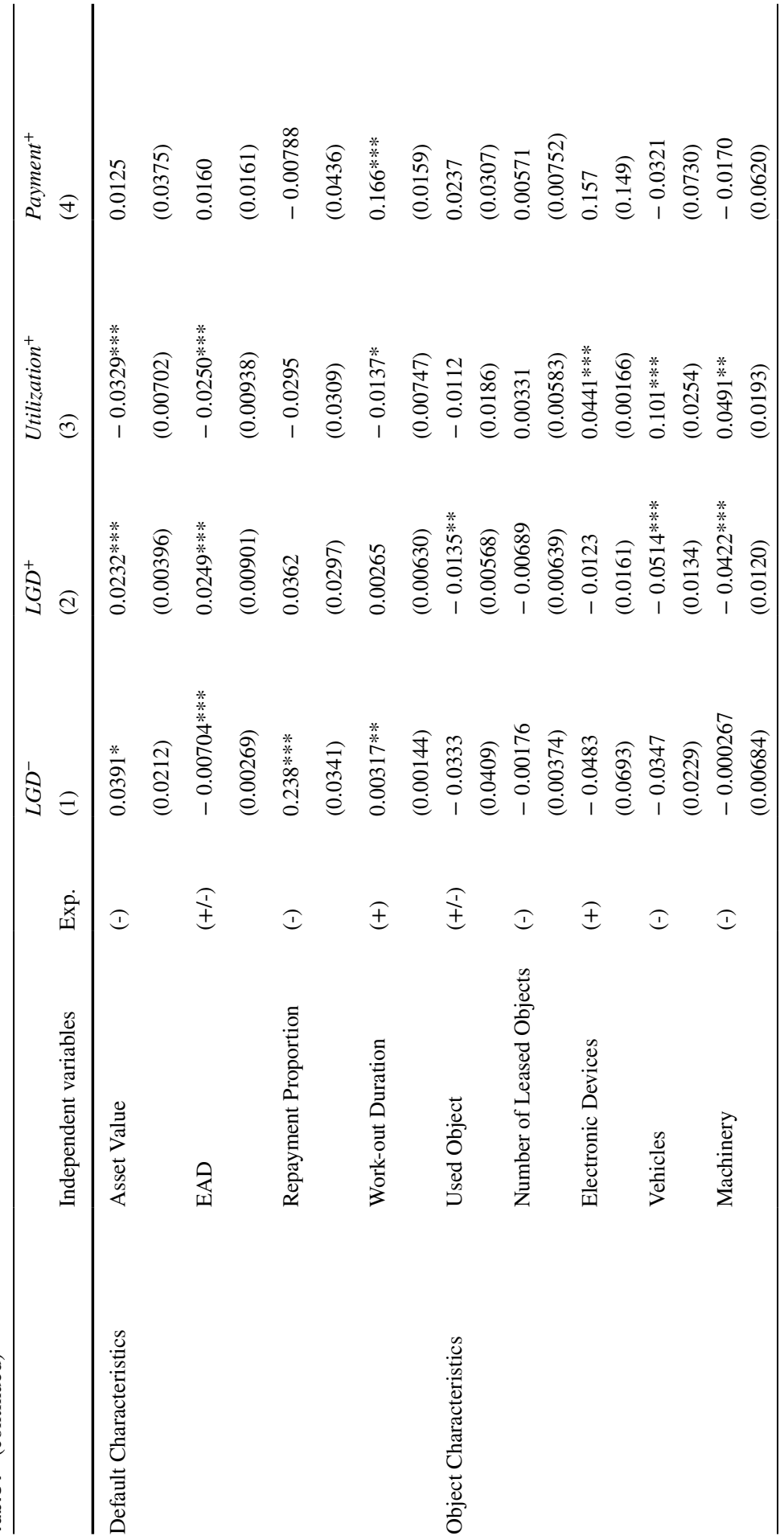




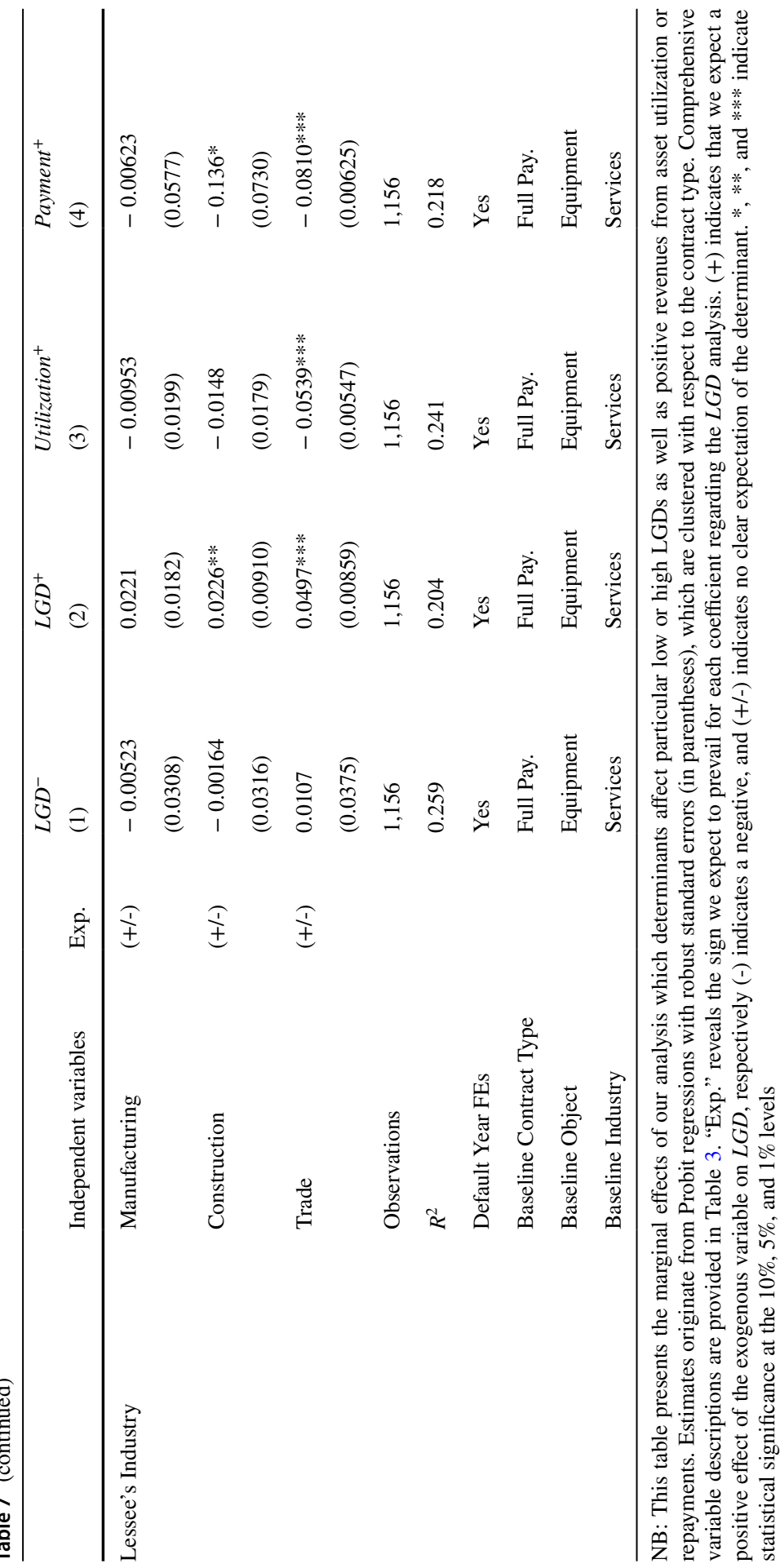




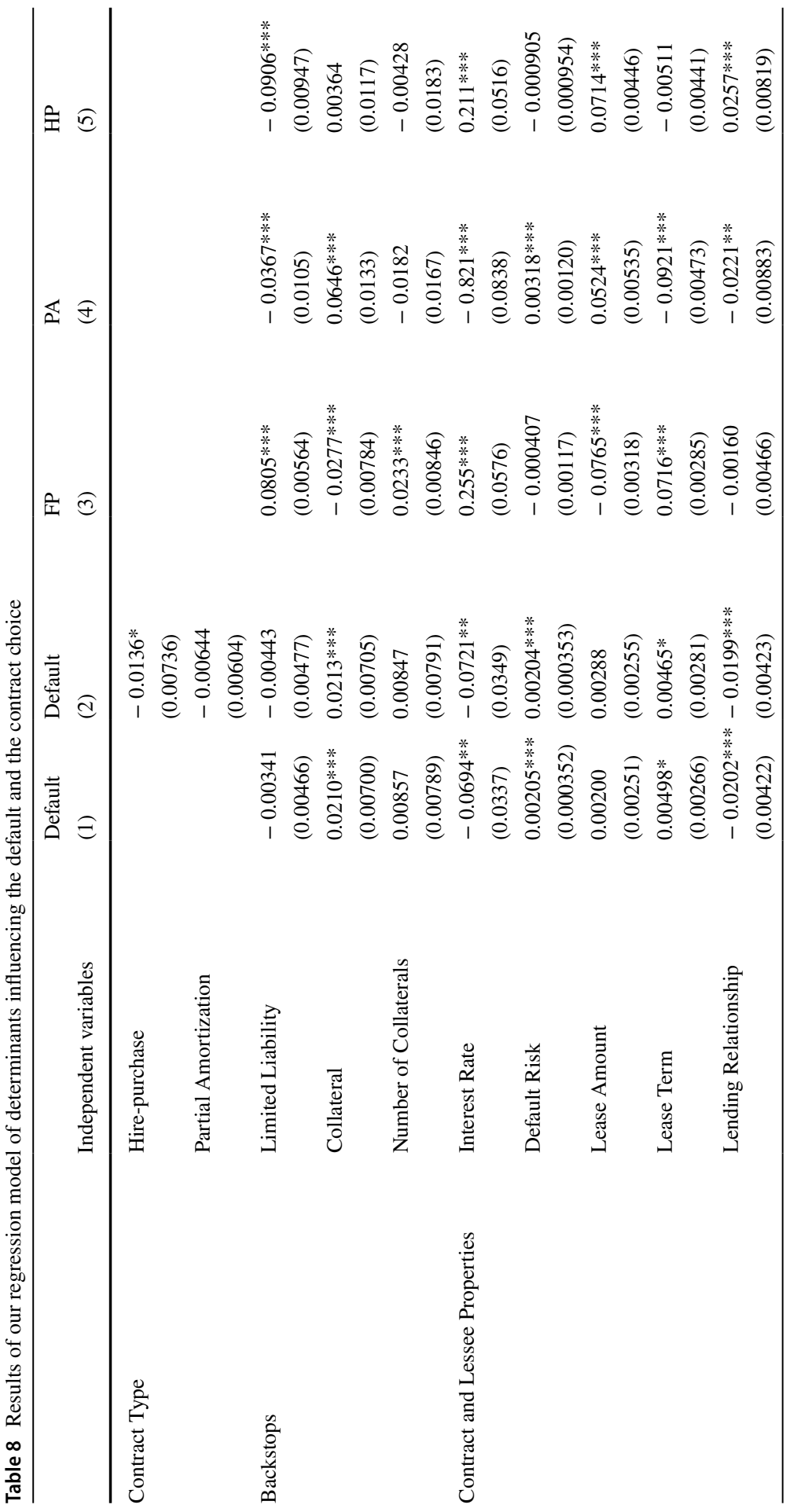




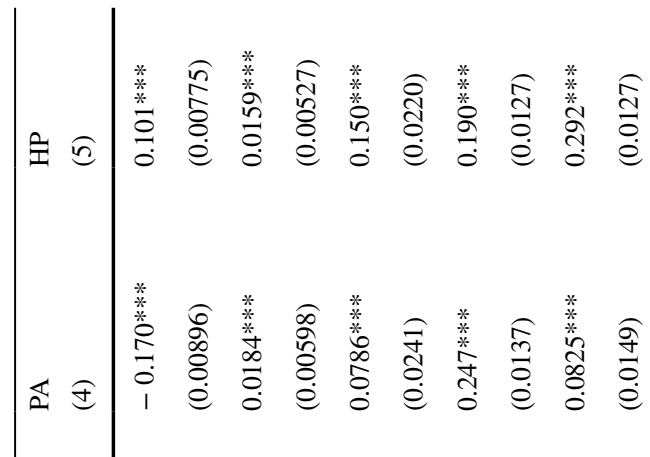

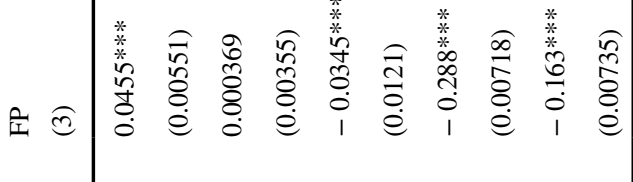

苞

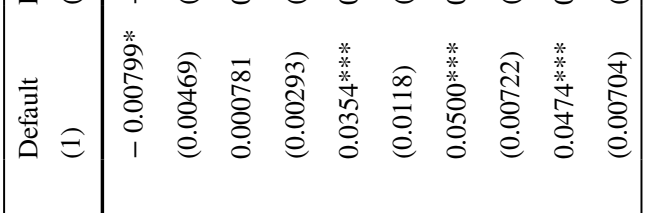

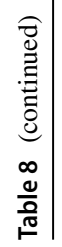

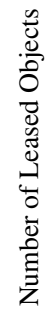

0
0
0
0
0
0
0
0
$\frac{0}{1}$
.1

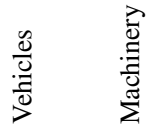




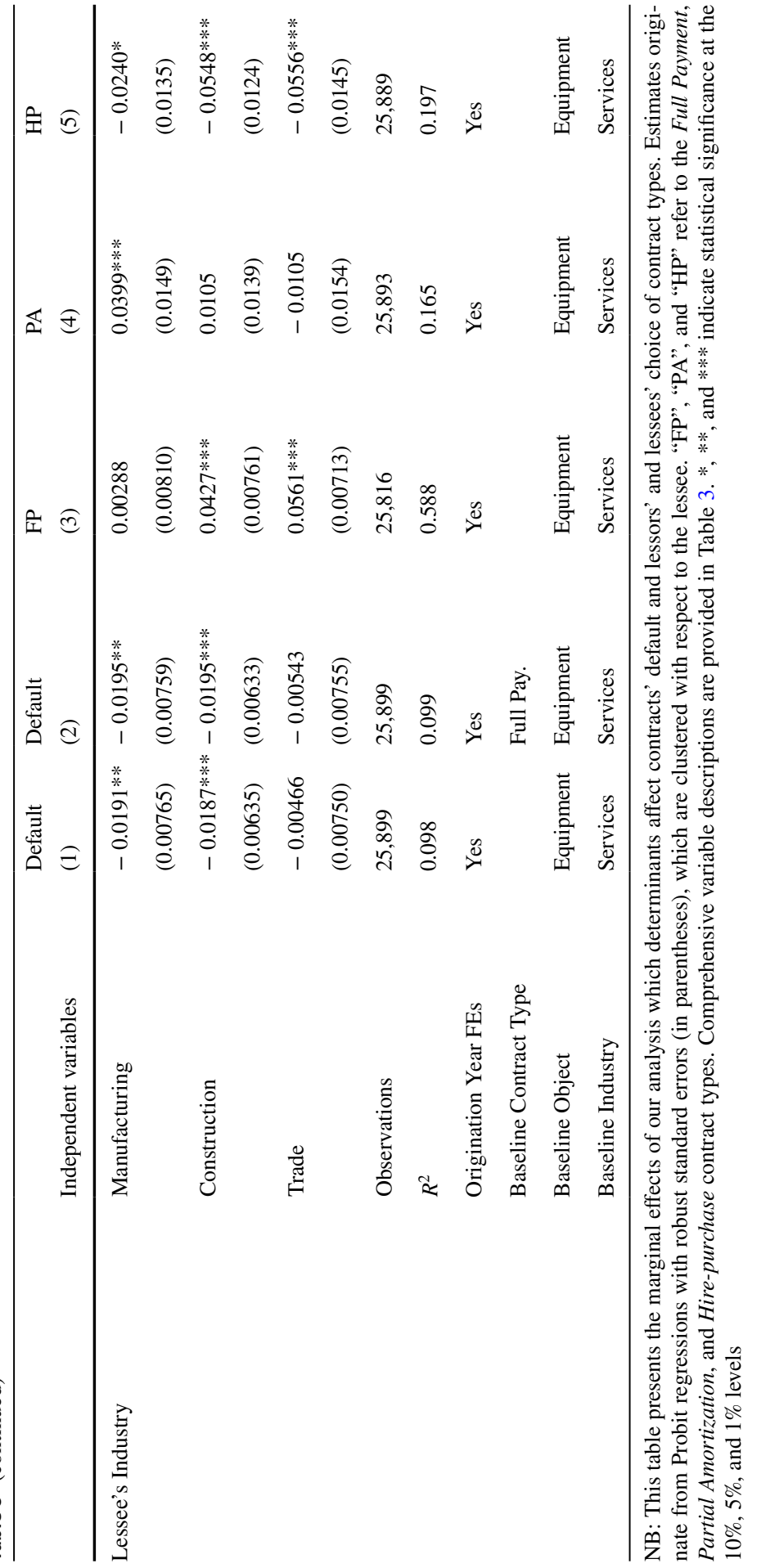




\section{Conclusions}

Lease contracts have emerged as a frequently used type of firm funding, especially for SMEs. This is engendered by unique contract characteristics such as the lessor remaining the legal owner of the leased asset during the lease term. Therefore, the repossession and utilization of the leased asset in case of lessee's default are significantly easier in leasing as compared to getting hold of collateral of loans or bonds. Consequently, the leased asset is of great importance for contract underwriting, lease risk estimation, and particularly the LGD and its determinants.

Against this background, our study explores novel as well as known lessee, leased asset, and contractual characteristics as determinants of the LGD and its major components in the leasing industry. We utilize a very granular data set of 26,750 lease contracts with SMEs from a mid-sized German bank covering 1156 contracts which defaulted between 2009 and 2014 and estimate several regression models with time FEs and clustered standard errors, as well as three different variable selection models. Our results reveal novel LGD determinants, for example, the number of leased assets and collaterals as well as the lessee's external credit rating and limited liability. Moreover, we find new evidence on previously explored influence factors, for example, the lease contract type, contradicting earlier findings. Most importantly, we also divide the LGD into two LGD variables, one based on the asset utilization proceeds, the other on repayments, and show that their separate analysis is of crucial significance, as their determinants fundamentally differ. Finally, we conduct several additional analyses to further demonstrate the robustness of our results.

Viewed holistically, our study assists both lessors and regulators in assessing the effective risk of lease contracts and also enables lessors to enhance their lease contract underwriting, monitoring activities, and organization of the recovery process by revealing novel insights into determinants of contracts' LGD. Given that leasing has become an important alternative for SME funding, this seems to be even more important, as the novel LGD input floor impelled by the upcoming Basel capital requirements determines the general minimum LGD values in the credit risk estimation (Basel Committee on Banking Supervision 2017, 2019). It is foreseeable that uniform LGD figures for loans and leases required by the regulator indeed inhibit lessors from considering leasing LGD particularities, as LGDs in leasing are exceptionally low and affected by a wide range of unique determinants. This in turn may actually impede leasing as a source of SME financing in the future (Haselmann and Wahrenburg 2016).

\section{Appendix}

Refer Table 9 


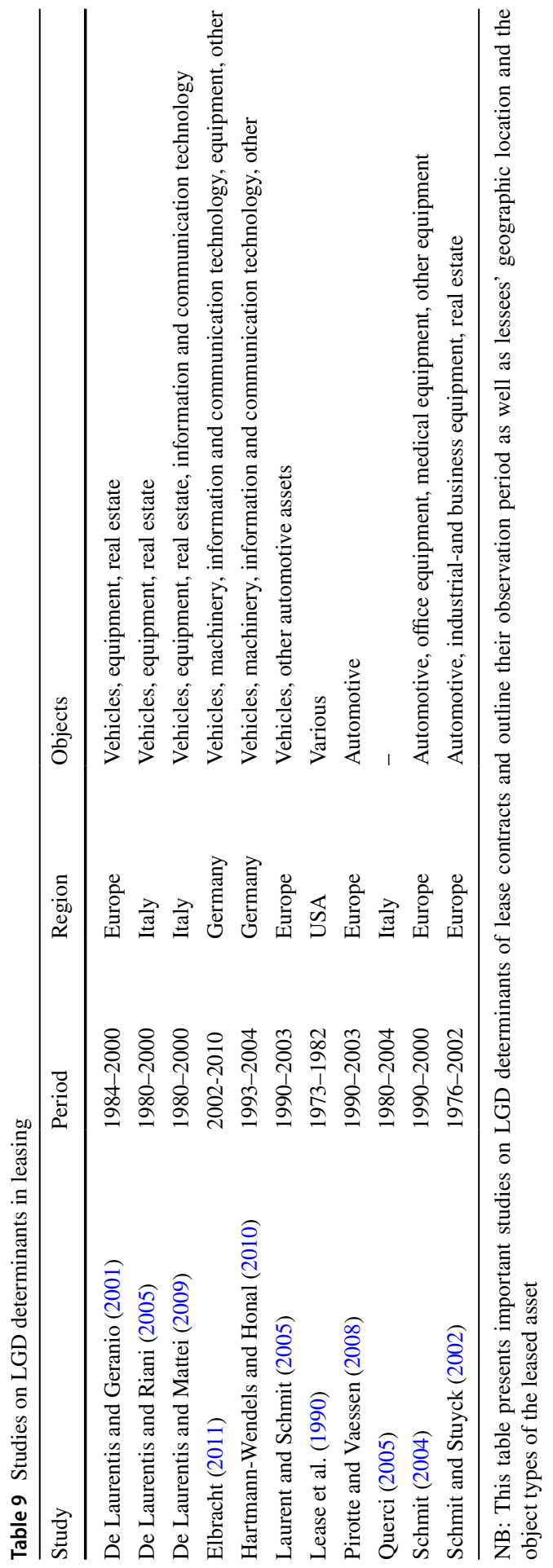


Supplementary Information The online version contains supplementary material available at. https://doi. org/10.1007/s11846-021-00486-5.

Funding Open Access funding enabled and organized by Projekt DEAL.

Open Access This article is licensed under a Creative Commons Attribution 4.0 International License, which permits use, sharing, adaptation, distribution and reproduction in any medium or format, as long as you give appropriate credit to the original author(s) and the source, provide a link to the Creative Commons licence, and indicate if changes were made. The images or other third party material in this article are included in the article's Creative Commons licence, unless indicated otherwise in a credit line to the material. If material is not included in the article's Creative Commons licence and your intended use is not permitted by statutory regulation or exceeds the permitted use, you will need to obtain permission directly from the copyright holder. To view a copy of this licence, visit http://creativecommons.org/licen ses/by/4.0/.

\section{References}

Agarwal S, Hauswald R (2010) Distance and private information in lending. Review Financ Stud 23:2757-2788

Altman EI, Brady B, Resti A, Sironi A (2005) The link between default and recovery rates: theory, empirical evidence, and implications. J Bus 78:2203-2228

Association of German Leasing Companies (2016) Annual report. https://bdl.leasingverband.de/internet/ downloads/Broschueren/The_German_Leasing_Market/Market_Report_Germany2015_final.pdf. Accessed 25 Aug 2021

Association of German Leasing Companies (2019) The members, https://bdl.leasingverband.de/mitgl ieder/die-mitglieder-des-bdl/. Accessed 21 Jan 2020

Bade B, Rösch D, Scheule H (2011) Default and recovery risk dependencies in a simple credit risk model. Eur Financ Manage 17:120-144

Basel Committee on Banking Supervision (2017) Finalising Basel III. Bank for International Settlements, December 2017

Basel Committee on Banking Supervision (2019) CRE32: IRB approach: Risk components for each asset class. Bank for International Settlements, December 2019

Bastos JA (2010) Forecasting bank loans loss-given-default. J Bank Finance 34:2510-2517

Berger AN, Udell GF (2006) A more complete conceptual framework for SME finance. J Bank Finance 30:2945-2966

Boot AWA (2000) Relationship banking: what do we know? J Financ Intermed 9:7-25

Boot AWA, Thakor AV (1994) Moral hazard and secured lending in an infinitely repeated credit market game. Int Econ Rev 35:899-920

De Laurentis G, Geranio M (2001) Leasing recovery rates. Leaseurope Working Paper

De Laurentis G, Mattei J (2009) Lessors recovery risk management capability. Manag Finance 35(10):860-873

De Laurentis G, Riani M (2005) Estimating LGD in the leasing industry: empirical evidence from a multivariate model. In: Altman EI, Resti A, Sironi A (eds) Recovery Risk. Risk Books, London, pp $143-164$

Dermine JM, Neto de Carvalho C (2006) Bank loan losses-given-default: a case study. J Bank Finance 30:1219-1243

Dietsch M, Petey J (2002) The credit risk in SME loans portfolios: modeling issues, pricing, and capital requirements. J Bank Finance 26:303-322

Eisfeldt AL, Rampini AA (2009) Leasing, ability to repossess, and debt capacity. Rev Financ Stud 22:1621-1657

Elbracht HC (2011) Statistische Methoden zur Quantifizierung und Schätzung des Loss Given Default. Finanzierung, Kapitalmarkt und Banken 78:1-113

Ertan A, Loumioti M, Wittenberg-Moerman R (2017) Enhancing loan quality through transparency: evidence from the European Central Bank loan level reporting initiative. J Account Res 55:877-918 
European Banking Authority (2017) Guidelines on PD estimation, LGD estimation and the treatment of defaulted exposures. https://www.eba.europa.eu/sites/default/documents/files/documents/10180/ 2033363/6b062012-45d6-4655-af04-801d26493ed0/Guidelines\%20on\%20PD\%20and\%20LGD\% 20estimation\%20\%28EBA-GL-2017-16\%29.pdf?retry=1. Accessed 25 Aug 2021

European Banking Authority (2019) Final Report : Guidelines for the estimation of LGD appropriate for an economic downturn (Downturn LGD estimation)

European Central Bank (2018) Survey on the access to finance of enterprises in the euro area: April to September 2018, https://www.ecb.europa.eu/stats/accesstofinancesofenterprises/pdf/ecb.safe2 01811.en.pdf. Accessed 21 Jan 2020

European Central Bank (2019) Survey on the access to finance of enterprises in the euro area: October 2018 to March 2019. https://www.ecb.europa.eu/stats/accesstofinancesofenterprises/pdf/ecb.safe2 01905 082335a4d1.en.pdf. Accessed 25 Aug 2021

Frank M, Goyal V (2009) Capital structure decisions: which factors are reliably important? Financ Manage 38:1-37

Franks J, de Servigny A, Davydenko S (2004) A comparative analysis of the recovery process and recovery rates for private companies in the UK, France and Germany. Standard \& Poor's Risk Solutions Working Paper

Grossman R, O’Shea S, Bonelli S (2001) Bank loan and bond recovery study. Fitch Loan Products Special Report

Grunert J, Weber M (2009) Recovery rates of commercial lending: empirical evidence for German companies. J Bank Finance 33:505-513

Hartmann-Wendels T, Honal M (2010) Do economic downturns have an impact on the loss given default of mobile lease contracts? - An empirical study for the German leasing market. Credit Capital Markets 43:65-96

Hartmann-Wendels T, Miller P, Töws E (2014) Loss given default for leasing: parametric and nonparametric estimations. J Bank Finance 40:364-375

Haselmann R, Wahrenburg M (2016) Banks' internal rating models - time for a change? The "system of floors" as proposed by the Basel committee. SAFE White Paper Series 43

Heckman JJ (1979) Sample selection bias as a specification error. Econometrica 47:153-161

Helwig PM (2008) Portfolioorientierte Quantifizierung des Adressenausfall- und Restwertrisikos im Leasinggeschäft - Modellierung und Anwendung. Fritz Knapp Verlag, Frankfurt a. M

Hu YT, Perraudin W (2006) The dependence of recovery rates and defaults. Risk Control Research Paper 6

Hurlin C, Leymarie J, Patin A (2018) Loss functions for loss given default model comparison. Eur J Oper Res 268:348-360

International Accounting Standards Board (2016) Effects Analysis International Financial Reporting Standard: IFRS 16 Leases

Jiménez G, Saurina J (2004) Collateral, type of lender and relationship banking as determinants of credit risk. J Bank Finance 28:2191-2212

Kaposty F, Kriebel J, Löderbusch M (2020) Predicting loss given default in leasing-a closer look at models and variable selection. Int J Forecast 36(2):248-266

Kraemer-Eis H, Lang F (2012) The importance of leasing for SME finance. EIF Research \& Market Analysis Working Paper 15

Krüger S, Oehme T, Rösch D, Scheule H (2018) A copula sample selection model for predicting multiyear LGDs and lifetime expected losses. J Empirical Finance 47:246-262

Kysucky V, Norden L (2016) The benefits of relationship lending in a cross-country context: a metaanalysis. Manage Sci 62:90-110

Lasfer M, Levis M (1998) The determinants of the leasing decision of small and large companies. Eur Financ Manage 4:159-184

Laurent MP, Schmit M (2005) Estimating distressed LGD on defaulted exposures: a portfolio model applied to leasing contracts. In: Altman EI, Resti A, Sironi A (eds) Recovery Risk. Risk Books, London, pp 307-322

Lease RC, McConnell JJ, Schallheim JS (1990) Realized returns and the default and prepayment experience of financial leasing contracts. Financ Manage 19:11-20

Leaseurope (2013) Implicit risk weights for SME leasing in Europe. https://www.leaseurope.org/_flysy stem/s3/Leaseurope\%20documents/Implicit\%20Risk\%20Weights\%20for\%20SME\%20Leasing\% 20in\%20Europe\%20-\%20Key\%20Findings.pdf. Accessed 25 Aug 2021

Leaseurope (2015) Annual survey 2015. https://www.leaseurope.org/_flysystem/s3/Statistics/European\% 20Leasing\%20Market\%202015.pdf. Accessed 25 Aug 2021 
Leaseurope (2016) Key facts and figures 2016. https://www.leaseurope.org/_flysystem/s3/Statistics/Lease uropeFF_16.pdf. Accessed 25 Aug 2021

Leaseurope (2017) Ranking of Top European Leasing Companies 2017. https://leasingsolutions.bnpparibas. com/en/wp-content/uploads/sites/5/2017/04/Leaseurope-Ranking-Survey-Press-Release.pdf. Accessed 25 Aug 2021

Leaseurope (2018) Leaseurope response to the European Commission consultation on the finalisation of Basel III. http://www.google.com/url?sa=t\&rct=j\&q=\&esrc=s\&source=web\&cd=\&cad=rja\& uact=8\&ved=2ahUKEwjItqGH2MvyAhXX_7sIHVo1DLYQFnoECAcQAQ\&url=https\%3A\%2F\% 2Fec.europa.eu\%2Feusurvey\%2Ffiles\%2Fa96dd5bb-3cae-4e4e-aa7d-fe932bd0c8e6\%2F21e677b9cf69-4e54-b0df-7667e380b116\&usg=AOvVaw00mT2KGwYcto838H8LDSUY. Accessed 25 Aug 2021

Miller P (2016) Modeling and Estimating the Loss Given Default of Leasing Contracts. PhD Thesis, University of Cologne

Miller P, Töws E (2018) Loss given default adjusted workout processes for leases. J Bank Finance 91:189-201

Oxford Economics (2015) The use of leasing amongst European SMEs. https://www.leaseurope.org/_ flysystem/s3/Leaseurope\%20documents/SME\%20Report\%202015\%20Key\%20Findings.pdf. Accessed 25 Aug 2021

Pan J, Singleton KJ (2008) Default and recovery implicit in the term structure of sovereign CDS spreads. J Finance 63:2345-2384

Pfister T, Utz S, Wimmer M (2015) Capital allocation in credit portfolios in a multi-period setting: a literature review and practical guidelines. Rev Manage Sci 11:1-32

Pirotte H, Vaessen C (2008) Residual value risk in the leasing industry: a European case. Eur J Finance 14:157-177

Pykhtin M (2003) Unexpected recovery risk. Risk 16:74-78

Querci F (2005) Loss given default on a medium-sized Italian bank's loans: an empirical exercise. University of Genova Working Paper 6

Rösch D, Scheule H (2014) Forecasting probabilities of default and loss rates given default in the presence of selection. J Oper Res Soc 65:393-407

Royston P, Sauerbrei W (2007) Multivariable modeling with cubic regression splines: a principled approach. Stata J 7(1):45-70

Schmit M (2004) Credit risk in the leasing industry. J Bank Finance 28:811-833

Schmit M, Stuyck J (2002) Recovery rates in the leasing industry. Leaseurope Working Paper

Sharpe SA, Nguyen HH (1995) Capital market imperfections and the incentive to lease. J Financ Econ 39:271-294

Tang Y, Deng C, Moro A (2017) Firm-bank trusting relationship and discouraged borrowers. Rev Manag Sci 11:519-541

Van de Castle K, Keisman D, Yang R (2000) Suddenly structure mattered: Insights into recoveries from defaulted debt. Standard \& Poor's Credit Week 5

Yashkir O, Yashkir Y (2013) Loss given default modeling: a comparative analysis. J Risk Model Valid 7:25-59

Publisher's Note Springer Nature remains neutral with regard to jurisdictional claims in published maps and institutional affiliations. 